\title{
Identification and selection of resistance to Bemisia tabaci among 550 cotton genotypes in the field and greenhouse experiments
}

\author{
Lizhen ZHU, Jianying LI, Zhongping XU, Hakim MANGHWAR, Sijia LIANG, Suli LI, Muna ALARIQI, \\ Shuangxia JIN (ه), Xianlong ZHANG
}

National Key Laboratory of Crop Genetic Improvement, Huazhong Agricultural University, Wuhan 430070, China

\begin{abstract}
Plants have developed sophisticated systems to cope with herbivore challenge, including morphological barriers and secondary metabolites to reduce damage. In this study, 550 Gossypium genotypes were evaluated for whitefly (Bemisia tabaci) resistance in five experiments including two in the field and three in the greenhouse, with 23 resistant and 19 susceptible genotypes selected. Whitefly-resistance index determination showed that a leaf having a high density of hairs had resistance to whitfly egg/nymph production. Longer leaf hairs were also important for resistance. This study revealed that okra shaped leaves reduced adult whitefly oviposition preference, while glabrous leaves and high hair density helped not only in the reduction of the adults but also decreased oviposition preference. Gossypol was also observed to be involved in the reduction of adult whitefly development and/or survival.
\end{abstract}

Keywords Bemisia tabaci, Gossypium genotypes, gossypol, leaf hair density, leaf hair length

\section{Introduction}

Cotton (Gossypium) is not only the source of the most important natural textile fiber, but also a significant oilyielding crop grown all over the world. Generally, four cultivated species are grown ${ }^{[1,2]}$. However, cotton production is severely affected by number of biotic and abiotic stresses $^{[3,4]}$ and it has been reported that in total 1326 species of insects attack cotton plants ${ }^{[5]}$. Some studies also reported that Bt-cotton plants provide substantial economic benefits and reduce the use of harmful insecticides ${ }^{[6,7]}$. The secondary pests such as aphids, mirid bugs and whiteflies

Received January 11, 2018; accepted March 28, 2018

Correspondence: jsx@mail.hzau.edu.cn are not susceptible to Bt-cotton plants and they directly benefit from reduced application of chemical insecticides ${ }^{[8-12]}$. Specifically, the mirid bugs (Heteroptera: Miridae) have shown tendency to produce outbreaks and were suggested to be considered as a primary target for development forecasting and management strategies in Btcotton fields in China ${ }^{[13-15]}$. Whiteflies are typical phloemfeeding insects and, as with other non-Bt target insects, tend to increase in Bt-cotton fields and have become a most devastating agricultural pest worldwide ${ }^{[16-19]}$. Moreover, whiteflies and aphids carry geminiviruses, which result in the spread of viral diseases ${ }^{[20-22]}$. The understanding of plant response mechanisms induced by herbivores can provide important information to assist in integrated pest management.

Plants and insects have coexisted for almost 350 million years and have evolved a variety of different interactions ${ }^{[23,24]}$. In nature, herbivores usually deal with multiple predators and plants as well as more complicated trophic influences ${ }^{[25,26]}$. Plants also have evolved distinct strategies to combat herbivores, physical barriers such as cell wall and cuticle as direct defenses and producing secondary metabolites in response to insect attack ${ }^{[19,27,28]}$. These two defense mechanisms against pests might operate synergistically ${ }^{[29]}$. The physical barriers, including hairs, trichomes, thorns, spines and thicker leaves on the surface of the plants, restrict or limit insect attack ${ }^{[30]}$. While, the production of primary and secondary metabolites, such as allelochemicals, non-protein amino acids, terpenoids, alkaloids, anthocyanins, phenols and quinones, may help in the reduction of growth, fecundity and survival of the insects ${ }^{[31-34]}$. It has been shown that phloem-feeding insects numbers are closely related to primary metabolite, such as amino acid and carbohydrate, concentrations in their host plants ${ }^{[33,35,36]}$. However, an overall understanding of how Bemisia tabaci adapts to the cotton host plants is still to be developed. 
Among the development of plant defense mechanisms, the distinctive essential role of capitate and peltate trichomes has been reported ${ }^{[37]}$. Capitate trichomes are the most important as they produce nonvolatile metabolic substances responsible for direct defense of plants ${ }^{[38,39]}$. Glandular trichomes produce, store and secrete metabolites of various classes which are associated with plant resistance to herbivores ${ }^{[17,37]}$. A negative correlation between trichome density and herbivore damage was found for this direct defense mechanism ${ }^{[34]}$. Moreover, increased trichome density can also be induced by herbivores and plant hormones ${ }^{[40]}$. Trichomes not only interfere with herbivore movement but also prevent egg attachment to plant tissues after ovipositioning ${ }^{[28]}$.

Leaf hair density has been linked to host plant resistance with lower populations of adult whiteflies being observed on glabrous leaves as compared to moderately hairy leaves giving a positive correlation between hair density and adult whitefly population ${ }^{[41-43]}$. Moreover, hair density also has impact on whitefly eggs and nymphs ${ }^{[42]}$. Whitefly oviposition preference has been compared across hairy, semi-glabrous and glabrous leaf isolines with a greater oviposition preference being found on hairy leaves by comparison with glabrous leaves ${ }^{[44]}$. In addition, another study has demonstrated that leaf hair length seemed to have an important role in insect resistance, with higher density of hair providing resistance to jassids ${ }^{[45]}$. Also, fewer whiteflies were observed on cotton leaves in the genotypes having okra shaped leaves compared to the normal leaf shape ${ }^{[42,46,47]}$. Miyazaki et al. ${ }^{[42]}$ and Chu et al. ${ }^{[47]}$ compared normal-leaf upland cotton cultivars with okraleaf genotypes, and lower numbers of adults, eggs and nymphs were found on okra-leaf genotypes because they provided a less desirable microenvironment with a more open canopy.

The glands of Gossypium plants produce a group of terpenoids, important secondary metabolites, which can protect plants from herbivorous insects ${ }^{[48-52]}$. Terpenoids defend many plants, animals and microorganisms against predators, pathogens and competitors, and are involved in conveying messages to conspecifics and mutualists regarding the presence of food, mates and enemies ${ }^{[53,54]}$.

Gossypol is one of the main components of glands, as well as other terpenoid aldehydes produced by subepidermal glands. They protect plants from some pathogenic bacteria and insect attack ${ }^{[55-57]}$. Cotton pigment glands and higher levels of gossypol resulted in a significant decrease in survival rates, larval weights and moth eclosion rates, and delayed not only the development of larvae and pupae, but also reduced the pupal weight of Helicoverpa virescens larvae ${ }^{[58,59]}$.

However, there have been few studies on the effect of pigment glands and gossypol on cotton resistance to whitefly. Our study assessed morphological traits (leaf shape, leaf hairiness, leaf hair length and gland density) and a secondary metabolite (gossypol) variation in a large number of cotton genotypes in relation to whitefly attack.

\section{Materials and methods}

\subsection{Identification of Bemisia tabaci biotype}

Whitefly adults were sampled from mature plants in a greenhouse and field experiments in the year of planting. Nymphs were sampled from one greenhouse screening (Exp. 3, see below). As the specimens were preserved in alcohol, they were briefly washed in sterile double distilled water before homogenization. The method of Barro and Driver ${ }^{[60]}$ was used with modifications as follows: from each sample, 3-5 whiteflies were transferred to a $1.5-\mathrm{mL}$ microcentrifuge tube and $100 \mu \mathrm{L}$ lysis buffer (1\% SDS,

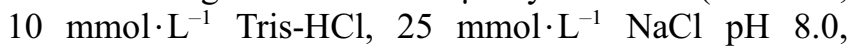
$25 \mathrm{mmol} \cdot \mathrm{L}^{-1}$ EDTA) added. Whitefly samples were ground using pestle and $100 \mu \mathrm{L}$ lysis buffer was used to clean the pestle, then $10 \mu \mathrm{L}$ of $20 \mathrm{mg} \cdot \mathrm{mL}^{-1}$ proteinase $\mathrm{K}$ was added to the tube and gently mixed. The homogenate was incubated at $60^{\circ} \mathrm{C}$ for $1 \mathrm{~h}$ (mixed every $20 \mathrm{~min}$ ), then at $100^{\circ} \mathrm{C}$ for $5 \mathrm{~min}$. After incubation, an equivalent volume of phenol:chloroform:isoamyl alcohol (25:24:1) was added to the microcentrifuge tube to extract whitefly DNA. The tubes were shaken gently by hand for $5 \mathrm{~min}$, then placed on ice for $10 \mathrm{~min}$, then the homogenate was centrifuged for $10 \mathrm{~min}$ at $12000 \mathrm{r} \cdot \mathrm{min}^{-1}$. The supernatant was transferred to a new microcentrifuge tube, and pre-cooled isopropyl alcohol $(400 \mu \mathrm{L})$ added and gently mixed before freezing at $-20^{\circ} \mathrm{C}$ for $20 \mathrm{~min}$. After thawing it was centrifuged for $10 \mathrm{~min}$ at $12000 \mathrm{r} \cdot \mathrm{min}^{-1}$, the supernatant was discarded, and $75 \%$ ethanol was used three times to wash the white sediment and then blown dry. Finally, the DNA samples were stored in TE buffer $(\mathrm{pH} 7.8)$ at $-20^{\circ} \mathrm{C}$.

For purification, DNA extraction was replicated three times, then $30 \mu \mathrm{L}$ of TE buffer (PH 7.8) was added and these DNA samples were used for PCR. Following the method of Rao et al. ${ }^{[61]}$, primers for CI-J-2195 (5'-TTG ATT TTT TGG TCA TCC AGA AGT-3') and L2-N-3014 (5'-TCC AAT GCACTA ATC TGC CAT ATT A-3') synthesized by the Jinsirui Company (Nanjin, JiangSu, China) were used. The method of Rao et al. ${ }^{[61]}$ was modified using a reaction volume of $20 \mu \mathrm{L}$ with $16.1 \mu \mathrm{L}$ of double distilled water, $10 \times$ PCR buffer $2 \mu \mathrm{L}$, dNTPs $0.3 \mu \mathrm{L}$, PCR primer $0.2 \mu \mathrm{L}$, Taq DNA polymerase $0.2 \mu \mathrm{L}$ and DNA template $1 \mu \mathrm{L}$ were added. The method of Simon et al. ${ }^{[62]}$ was used for the reaction procedure and PCR amplification. Agarose gels (1.5\%) were used to run PCR product on electrophoresis.

\subsection{Experimental design and plant genotype}

Greenhouse screening experiments were conducted in August to December 2013 (Exp. 1), March to July 2014 
(Exp. 2) and October 2014 to January 2015 (Exp. 3). Two field screening experiments were conducted, 2014-2015 growing season (Exp. 4) and 2015-2016 growing season (Exp. 5), at Wuhan, Hubei, China. The genotypes used in each experiment were 498 Gossypium hirsutum, 35 G. barbadense, 12 G. arboreum, and 5 G. herbaceum (Fig. 1). Among these genotypes were plants with differences in morphology of leaf shape, leaf hairiness, leaf hair length and possibly biochemistry.

(a)

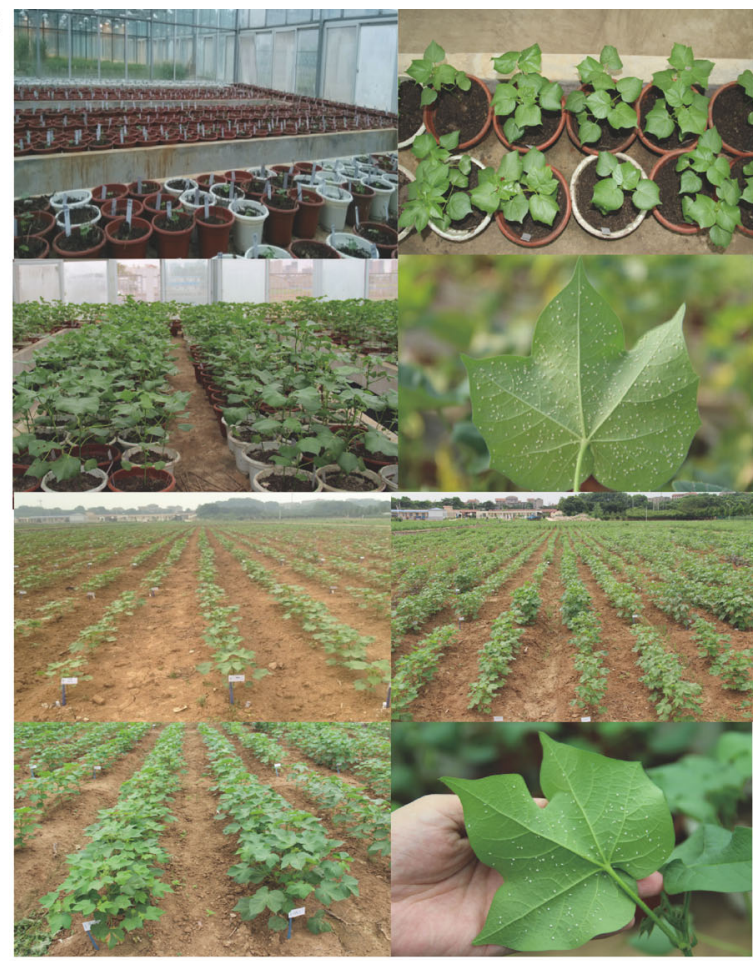

(b)

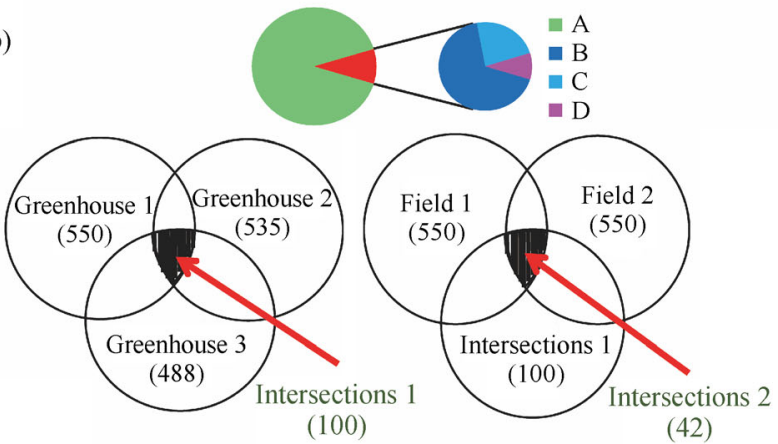

Fig. 1 Bioassay of 550 cotton genotypes under greenhouse and field conditions. (a) The greenhouse experiments were conducted from August to December 2013 (Exp. 1), March to July 2014 (Exp. 2) and October 2014 to January 2015 (Exp. 3). Each greenhouse had the same experimental treatment. The field experiments were conducted in the 2014-2015 growing season (Exp. 4) and 20152016 growing season (Exp. 5), each field plot was given the same treatment; (b) A, G. hirsutum $(n=498)$; B, G. barbadense $(n=35)$; C, G. arboreum $(n=12)$; D, G. herbaceum $(n=5)$. Red arrows indicate the number of genotypes in common for greenhouse (100) and field (42) experiments.

\subsection{Design of greenhouse experiments $1-3$}

Five hundred and fifty cotton genotypes were grown in greenhouses that were completely cleaned and sprayed with insecticides and then closed for one week. Heattreated soil was moved to greenhouse. The greenhouse experiment was a randomized complete block design with three blocks and 550 genotypes (550 in greenhouse 1, 535 in greenhouse 2, and 488 in greenhouse 3) (Fig. 1). Each genotype had three replicates and each replicate had at least two consistent growth opportunities. The experiments were conducted without any further pesticide treatments throughout the growing period. When the main cotton stem had five leaves, tobacco plants infested with whiteflies were uniformly distributed across the whole greenhouse to spread whiteflies.

Three weeks after infestation, the number of whitefly adults on the underside of five leaves from the top to bottom of the cotton plants were counted by turning the leaves over carefully. The counting time 06:30-08:30 and 17:30-19:30 because at those times the whiteflies were inactive. Also, a sample from the leaves from Exps. 2-3 were taken, mixed together and stored at $-70^{\circ} \mathrm{C}$ for the determination of gossypol concentration.

\subsection{Design of field experiments 4-5}

In mid-April 2014 and 2015, fertile soil and a small propagating shed were used to ensure higher germination rate and uniformity. Cotton seedlings were transplanted into the field in the mid-May and no pesticides were applied during the whole growth period. The experiments were randomized complete block design with a buffer around the periphery and each genotype had 10 replications. On 20 June 2014, whitefly assessment commenced and was then conducted monthly throughout the growth period of cotton. During mid-August 2014, the whitefly population reached its peak. The population of adult whiteflies was counted on the underside of five leaves from the top to the bottom by turning the leaves over carefully. In both years, assessments were made between 06:00 08:00 and 18:00-20:00.

\subsection{Design of greenhouse experiments 6-7}

Two futher greenhouse screening experiments were conducted in March to July 2014 (Exp. 6) and October 2014 to January 2015 (Exp. 7) that paralleled Exps. 2-3. Forty cotton genotypes identified and selected from Exp. 1 were used for the assessment of leaf hair length and density, leaf glands and gossypol concentration.

\subsection{Assessment of egg and nymph density}

Assessment of egg and nymph density was made in Exps. 2-3. Nymphs were counted after counting the adults 
3 weeks after infestation by turning the leaves over and brushing all the adult whiteflies from the leaf. Eggs and nymphs were counted on the third main stem leaf from the top of cotton plants from photographs taken with a Leica stereo microscope. The mean number was calculated for each replicate at each assessment date. Leaf area was calibrated using photographs of Vernier calipers taken at the same scale. The final totals of eggs and nymphs were determined for each of the three biological replicates.

\subsection{Assessment of leaf hair length and density and glands}

Assessment of leaf hair length and density and the number of glands was conducted in Exps. 6-7. The main stem with five leaves is the preferred sampling position for commercial cotton crops $^{[63]}$, so the third main stem node leaf from the top of cotton plant was selected from three stems to make a triangle. Scanning electron microscopy was used to study the leaf morphology. Photographs of the underside of the leaves were taken at the same magnification and were used to count the number of leaf hairs and glands, and to measure leaf hair length (Fig. 2). The means from the photographs were calculated for each replicate at each assessment. All genotypes were assessed three times. Finally, the photograph magnification was used to calculate leaf hair density.

\subsection{Assessment of gossypol concentrations}

Assessment of leaf gossypol was made in Exps. 6-7. High performance liquid chromatography (HPLC) was used to optimize the quantitative determination of free gossypol in the cotton leaves.

When the main stem node of cotton plants had five leaves, three samples were selected from the remaining four plants. Second and third main stem node leaves from the top cotton plant were selected. A vacuum freeze-drier was used to dry the cotton leaves at $-50^{\circ} \mathrm{C}$. The freezedried leaves were crushed with a mixer mill (MM 400, Retsch, Haan, Germany) with zirconia beads for $1.5 \mathrm{~min}$ at $30 \mathrm{~Hz}, 100 \mathrm{mg}$ powder was weighed and extracted with acetonitrile and water $(65: 35, \mathrm{~V} / \mathrm{V})$ by ultrasound, vibration, centrifugation and suction filter processing before HPLC analysis.

The optimal conditions of HPLC were as follows: the column was Agilent TC-C (18) $(150 \mathrm{~mm} \times 4.6 \mathrm{~mm}, 5 \mu \mathrm{m})$, and the mobile phase was a mixture of acetonitrile and $0.2 \%$ phosphoric acid $(85: 15, \mathrm{~V} / \mathrm{V})$ with a flow rate of $1.0 \mathrm{~mL} \cdot \mathrm{min}^{-1}$. The wavelength for UV detection was $238 \mathrm{~nm}$, the injected sample volume $20 \mu \mathrm{L}$ and the column temperature $25^{\circ} \mathrm{C}$.

\subsection{Statistical analysis}

The data for adult whiteflies were obtained by determining the total number on the top five leaves of each cotton genotype. The results were statistically analyzed by ANOVAR using SPSS 17.0. The number of nymphs, leaf hairs, glands and leaf hair length on each photo were calculated per $\mathrm{cm}^{2}$. These densities and relationships were analyzed as previously published ${ }^{[64]}$. Square-root transformed data for gland density was used for statistical analysis.

Relative weight analysis was used to estimate which factors were stronger correlation predictors ${ }^{[65]}$. Relative weight analysis of the relationship between cotton morphological traits (leaf shape, and leaf hair density and length), the concentration of gossypol and number of glands on adult whitefly populations and nymph density was performed using $\mathrm{R}$ software v. 3.2.2 (R Core Team (2016). R: a language and environment for statistical computing. R Foundation for Statistical Computing, Vienna, Austria).

\section{Results}

\subsection{Biotype identification of the Bemisia tabaci}

PCR bands for the whitefly extract were found at about 680 bp (Fig. S1a). The whitefly mtDNA COI sequences (EU376994, AJ867555, AY686088, AY686089, EU376987, GQ139500, DQ365874, EF080823, EU760719 and EU099430) representative of different geographic populations was download from NCBI. Homology analysis showed that whiteflies from greenhouse and field experiments were both Q-biotypes and these sequences had significantly higher homology with EU376987 than other sequences: $99.1 \%, 98.8 \%, 99.0 \%$, 99.7\%, and $99.8 \%$ for Exps. 1-5, respectively. Molecular phylogenetic trees for $B$. tabaci constructed by the UPGMA method with bootstrap test in MEGA 6.0 (Fig. S1b) also indicated that B. tabaci from the experiments were closely related to GQ139500, EF080823 and EU376987.

\subsection{Screening of resistant/susceptible cotton genotypes}

A total of 550 cotton genotypes, selected from three main cotton cultivation regions in China, Yangzi River valley, Yellow River and Xinjiang, were infested with whiteflies in a greenhouse were sampled with three biological replicates and two bioassays in the field (campus of Huazhong Agricultural University) in three consecutive growing seasons (August 2013 to August 2015). In the greenhouse experiment, when the main-stem of cotton plants had five true leaves, tobacco plants with whiteflies were used to infest the cotton plants until the whiteflies were distributed uniformly. Three weeks later, the whitefly adults on each replicate of the 550 genotypes were counted.

Stability and comparative analysis of adult whitefly 


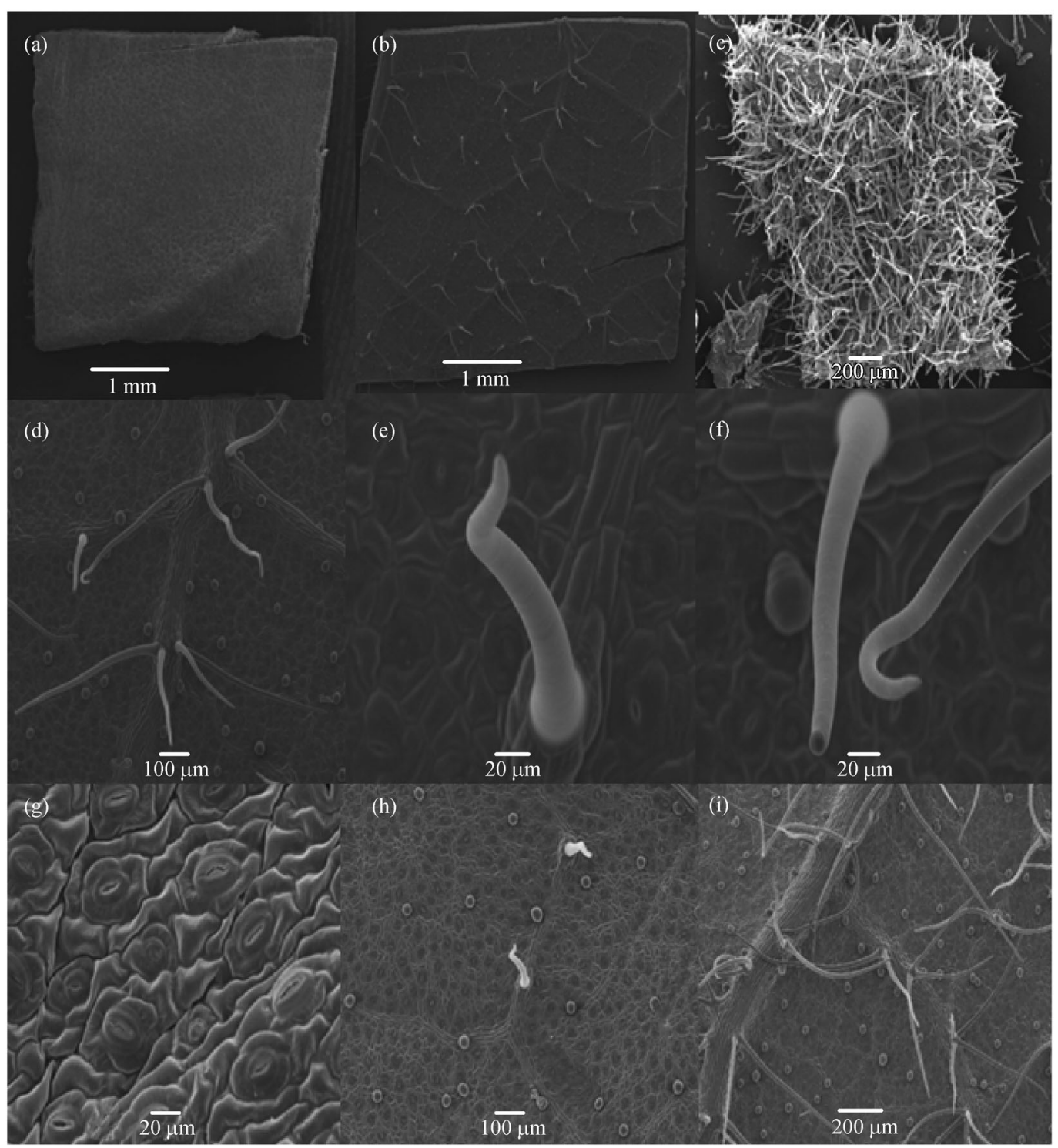

Fig. 2 Cotton leaf morphology related to resistance to whitefly in greenhouse Exps. 6-7. (a-c) Genotypes with different hair densities; $(\mathrm{d}-\mathrm{f})$ genotypes with different hair length; $(\mathrm{g}-\mathrm{i})$ gland on the leaf surface. All the photographs were taken by scanning electron microscopy.

populations with three biological replicates showed that 42 selected cotton genotypes (40 G. hirsutums, one G. arboretum and one G. herbaceum), which included 23 resistant and 19 susceptible genotypes, exhibited a consistent performance in resistance and susceptibility in three greenhouses and two field experiments (Fig. 1a). The morphological traits (leaf shape, leaf hairiness, leaf hair length and gland density) (Table 1) and secondary metabolism (gossypol) were observed for each of these genotypes.

To further categorize resistance/susceptibility profiles of these cotton genotypes, cluster analysis was performed on the Euclidean distance metric of each species and the cluster results were visualized in $\mathrm{R}$ with 'cluster' package ${ }^{[66]}$. This analysis showed that the resistant genotypes were all clustered in one group while the susceptible species were in another (Fig. 3a). In addition, the reproducibility of these experiments was tested through the comparative analysis of adult whitefly populations differentiation from Exps. 1-3 in the greenhouse, and Exps. 4-5 in the field. The resulted showed a significance level of $\mathrm{P}<0.05$ (Fig. 3b). 
Table 1 Details of genotypes identified and selected in three greenhouse experiments (Exps. 1-3 and two field (Exps. 4-5) experiments

\begin{tabular}{|c|c|c|c|c|}
\hline Genotype & Experiment & Species & Leaf shape & Leaf hairs \\
\hline SM8 & $1,2,3,4,5$ & G. hirsutum & Normal & Normal \\
\hline DZMSR1 & $1,2,3,4,5$ & G. hirsutum & Normal & Normal \\
\hline JM20 & $1,2,3,4,5$ & G. hirsutum & Normal & Normal \\
\hline $\mathrm{X} 16$ & $1,2,3,4,5$ & G. hirsutum & Normal & Normal \\
\hline ZLZ & $1,2,3,4,5$ & G. hirsutum & Normal & Normal \\
\hline GL1 & $1,2,3,4,5$ & G. hirsutum & Normal & Normal \\
\hline Z1-59 & $1,2,3,4,5$ & G. hirsutum & Normal & Normal \\
\hline $37-30$ & $1,2,3,4,5$ & G. hirsutum & Normal & Normal \\
\hline $38-36$ & $1,2,3,4,5$ & G. hirsutum & Normal & Normal \\
\hline $39-38$ & $1,2,3,4,5$ & G. hirsutum & Normal & Normal \\
\hline PZYH & $1,2,3,4,5$ & G. hirsutum & Normal & Normal \\
\hline $\operatorname{ACS} 50 / 2$ & $1,2,3,4,5$ & G. hirsutum & Normal & Normal \\
\hline 3196 & $1,2,3,4,5$ & G. hirsutum & Normal & Normal \\
\hline LBM & $1,2,3,4,5$ & G. hirsutum & Normal & Hairy \\
\hline $481 \mathrm{GZ}$ & $1,2,3,4,5$ & G. hirsutum & Normal & Hairy \\
\hline $74 s-237$ & $1,2,3,4,5$ & G. hirsutum & Normal & Hairy \\
\hline L1779 & $1,2,3,4,5$ & G. hirsutum & Normal & Hairy \\
\hline LM1 & $1,2,3,4,5$ & G. hirsutum & Normal & Hairy \\
\hline ZYZ4 & $1,2,3,4,5$ & G. arboreum & Okra & Hairy \\
\hline DH77-116 & $1,2,3,4,5$ & G. hirsutum & Normal & Hairy \\
\hline MYm20 & $1,2,3,4,5$ & G. hirsutum & Normal & Glabrous \\
\hline HM4 & $1,2,3,4,5$ & G. hirsutum & Normal & Glabrous \\
\hline L901-902 & $1,2,3,4,5$ & G. hirsutum & Normal & Glabrous \\
\hline YJ2 & $1,2,3,4,5$ & G. hirsutum & Normal & Glabrous \\
\hline Z161 & $1,2,3,4,5$ & G. hirsutum & Normal & Glabrous \\
\hline LJM5 & $1,2,3,4,5$ & G. hirsutum & Normal & Glabrous \\
\hline L96-103 & $1,2,3,4,5$ & G. hirsutum & Normal & Glabrous \\
\hline 13Р022 & $1,2,3,4,5$ & G. hirsutum & Normal & Glabrous \\
\hline JN804 & $1,2,3,4,5$ & G. hirsutum & Normal & Normal \\
\hline HMJw & $1,2,3,4,5$ & G. hirsutum & Normal & Normal \\
\hline GL3 & $1,2,3,4,5$ & G. hirsutum & Normal & Normal \\
\hline RO & $1,2,3,4,5$ & G. herbaceum & Okra & Normal \\
\hline $39-24$ & $1,2,3,4,5$ & G. hirsutum & Normal & Normal \\
\hline $38-34$ & $1,2,3,4,5$ & G. hirsutum & Normal & Normal \\
\hline DGZ8-9 & $1,2,3,4,5$ & G. hirsutum & Normal & Normal \\
\hline $13 \mathrm{p} 027$ & $1,2,3,4,5$ & G. hirsutum & Normal & Normal \\
\hline ZMS22 & $1,2,3,4,5$ & G. hirsutum & Normal & Normal \\
\hline 6919 & $1,2,3,4,5$ & G. hirsutum & Normal & Normal \\
\hline QM465 & $1,2,3,4,5$ & G. hirsutum & Normal & Normal \\
\hline ZM3 & $1,2,3,4,5$ & G. hirsutum & Normal & Normal \\
\hline $13 \mathrm{p} 023$ & $1,2,3,4,5$ & G. hirsutum & Normal & Normal \\
\hline HM11046 & $1,2,3,4,5$ & G. hirsutum & Normal & Normal \\
\hline
\end{tabular}




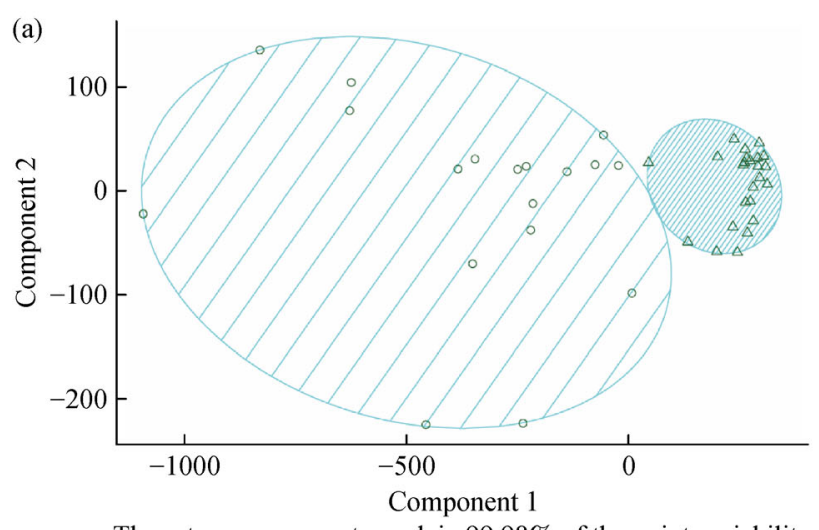

These two components explain $99.98 \%$ of the point variability

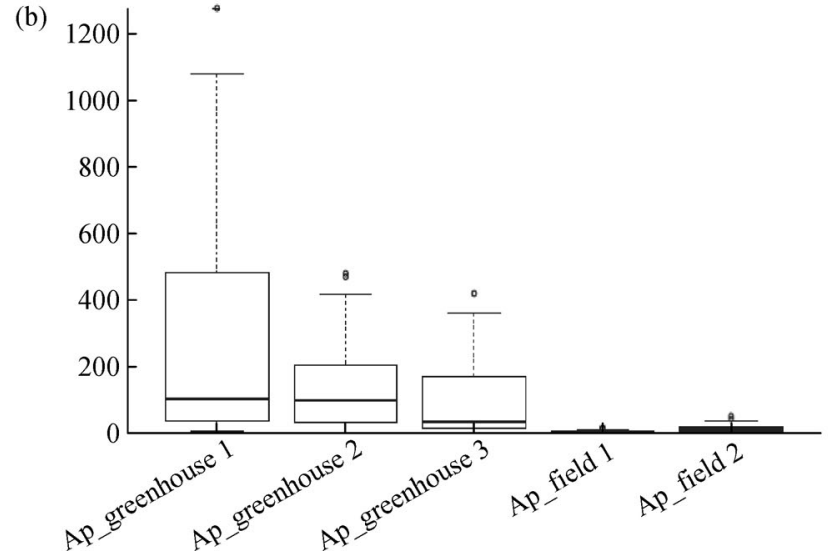

Fig. 3 Comparative analysis and Clusplot of adult whitefly populations in Exps. 1-3 in greenhouse and Exps. 4-5 in the field. (a) Clusplot of the first two components of 42 genotypes including susceptible and resistant genotypes with the population assessment of whitefly adults. To further categorize the resistance/susceptibility profiles of these different species of upland cotton, a cluster analysis was performed on the Euclidean distance metric of each species and the cluster results visualized in $\mathrm{R}$ with cluster package. The resistant species were clustered in one group and susceptible species in another group; (b) differentiation was supported by the $t$-test at a significance level of $P<0.05$.

3.3 Screening of adult whitefly populations in greenhouse and field

The SPSS software was used to analyze the individual results for susceptible and resistant genotypes. The total number of adult whiteflies per five leaves in the greenhouse and field experiment plots was the highest in DH77116 (mean of 447.133 adults per five leaves), which was five times higher than the lowest genotype, DGZ8-9 (mean of 89.8 adults per five leaves), from the susceptible genotypes (Table 2).

Adult whitefly populations combined with morphological traits of each genotype were used to ensure the stability and accuracy of resistant/susceptible genotypes. Susceptible genotypes of $G$. hirsutum with normal leaf shape had significantly higher numbers of adult whiteflies than other genotypes.

\subsection{Nymph densitis in greenhouse experiments 2-3}

Forty resistant/susceptible genotypes (some different from the 42 genotypes assessed for adult whiteflies) were assessed for nymph density. Of these, 25 genotypes common to the two groups were selected. When comparing the adult and nymphs density between (a) and (b) and between (c) and (d) in Fig. S2, no significant differences were detected among the selected genotypes. The nymph density across two experiments was the highest in DH77116 (1450.571and 3359.227 per $\mathrm{cm}^{2}$ in Exps. 2-3, respectively), which had more than seven times the density of HM4 (2.00 and 4.30 per $\mathrm{cm}^{2}$ in Exps. 2-3, respectively) (Table S1; Fig. 4), and had significantly higher densities than all other genotypes. However, the number of eggs and nymphs on G. hirsutum genotype L1779, which had the highest leaf hair density and length, were significantly higher than all other G. hirsutum genotypes (Fig. 4).

\subsection{Leaf hair density and length on the undersides of leaves}

The 25 genotypes (10 susceptible and 15 resistant), which consisted of eight glabrous (HM4, MY4 and L901-902 being susceptible, and YJ2, 13P022, L96-103, LJM5 and Z161 being resistant), seven hairy (DH77-116, 481GZ, 74 s-237 and LBM being susceptible, and L1779, ZLZ and ZYZ4 being resistant) and 10 normal genotypes, were assessed for leaf hair density. In greenhouse Exps. 2-3, the density of leaf hairs on three genotypes (DH77-116, $481 \mathrm{GZ}$ and $74 \mathrm{~s}-237$ ) was significantly higher than all other genotypes (susceptible listing in Table 3), and more than eight times the density of the normal genotype 6919 (Table 3). Furthermore, when comparing the leaf hair density (Table 3 ) with the number of whitefly eggs and nymphs (Table S1) in resistant/susceptible genotypes, it was found that the number of whitefly eggs and nymphs showed an increasing trend when the density of hairs was ultra-high (ZLZ had higher leaf hair density, and number of whitefly eggs and nymphs than JM20) or ultra-low (SM8 had lower leaf hair density but higher number of whitefly eggs and nymphs than L96-103) in resistant genotypes. In contrast, ultra high density of hairs resulted in a relatively low number of whitefly eggs and nymphs $(481 \mathrm{GZ}$ had a higher density of hair but lower number of whitefly eggs and nymphs than DH77-116) in susceptible genotypes. Notably, all glabrous genotypes had fewer whitefly eggs and nymphs. So, it was concluded that low leaf hair density contributed to resistance to egg/nymph production. 
Table 2 Mean number of adult whiteflies per five leaves on susceptible and resistant genotypes in greenhouse (Exps. 1-3) and field (Exps. 4-5) experiments

\begin{tabular}{|c|c|c|c|c|c|c|c|c|c|c|c|c|c|}
\hline \multirow{3}{*}{$\begin{array}{l}\text { Phenotype } \\
\text { Susceptible }\end{array}$} & \multirow{3}{*}{$\begin{array}{l}\text { Genotype } \\
\text { MYm20 }\end{array}$} & \multicolumn{12}{|c|}{ Adults per five leaves } \\
\hline & & \multicolumn{2}{|c|}{ Exp. 1} & \multicolumn{2}{|c|}{ Exp. 2} & \multicolumn{2}{|c|}{ Exp. 3} & \multicolumn{2}{|c|}{ Exp. 4} & \multicolumn{2}{|c|}{ Exp. 5} & \multicolumn{2}{|c|}{ Mean } \\
\hline & & 443.667 & $\mathrm{f}$ & 415.667 & $a b$ & 288.333 & $\mathrm{~b}$ & 5.333 & $\mathrm{~cd}$ & 18 & $\mathrm{~d}$ & 181.833 & d \\
\hline & JN804 & 641.667 & $\mathrm{~d}$ & 480 & $\mathrm{a}$ & 213.333 & $\mathrm{~cd}$ & 10.667 & $\mathrm{bc}$ & 34.333 & $\mathrm{bc}$ & 276 & $\mathrm{~cd}$ \\
\hline & 3196 & 256.333 & $\mathrm{~h}$ & 224 & $\mathrm{bc}$ & 81.333 & e & 7.667 & $\mathrm{~cd}$ & 22.667 & $\mathrm{~cd}$ & 118.5 & ef \\
\hline & DH77-116 & 1277 & a & 470 & $a b$ & 420 & $\mathrm{a}$ & 17.333 & a & 51.333 & $\mathrm{a}$ & 447.133 & $\mathrm{a}$ \\
\hline & $\mathrm{X} 16$ & 355.333 & $\mathrm{~g}$ & 97.333 & $\mathrm{~d}$ & 118.333 & de & 3.333 & d & 13.7 & $\mathrm{~d}$ & 117.606 & ef \\
\hline & HMJw & 364.667 & $\mathrm{~g}$ & 130 & $\mathrm{bc}$ & 120.667 & de & 7.333 & $\mathrm{~cd}$ & 21 & $\mathrm{~cd}$ & 128.733 & ef \\
\hline & LBM & 504 & ef & 177 & $\mathrm{bc}$ & 171.667 & de & 6.333 & $\mathrm{~cd}$ & 19.7 & $\mathrm{~cd}$ & 175.74 & de \\
\hline & GL3 & 885.667 & $\mathrm{c}$ & 213 & $\mathrm{bc}$ & 293.667 & $\mathrm{~b}$ & 7 & $\mathrm{~cd}$ & 27 & $\mathrm{c}$ & 285.267 & $\mathrm{c}$ \\
\hline & $38-34$ & 1081 & $\mathrm{~b}$ & 243 & $\mathrm{bc}$ & 360 & $a b$ & 11.333 & $\mathrm{bc}$ & 35 & $\mathrm{bc}$ & 346.067 & $\mathrm{~b}$ \\
\hline & $39-24$ & 479 & ef & 232 & $\mathrm{bc}$ & 159.667 & de & 6.333 & $\mathrm{~cd}$ & 20 & $\mathrm{~cd}$ & 179.4 & de \\
\hline & DGZ8-9 & 255.667 & $\mathrm{~h}$ & 93.3 & $\mathrm{~d}$ & 85 & e & 4.333 & d & 10.667 & d & 89.793 & $\mathrm{f}$ \\
\hline & 13p027 & 316.667 & gh & 116 & c & 105.333 & e & 4 & d & 12.667 & d & 110.933 & ef \\
\hline & ZMS22 & 880.667 & $\mathrm{c}$ & 240 & $\mathrm{bc}$ & 293.3 & $\mathrm{~b}$ & 13 & $\mathrm{~b}$ & 42.7 & $\mathrm{~b}$ & 293.933 & $\mathrm{bc}$ \\
\hline & $481 \mathrm{GZ}$ & 481.667 & ef & 207 & $\mathrm{bc}$ & 160 & de & 5.667 & $\mathrm{~cd}$ & 20.333 & $\mathrm{~cd}$ & 174.933 & de \\
\hline & $74 s-237$ & 589.333 & de & 301 & $\mathrm{~b}$ & 195.333 & $\mathrm{~cd}$ & 8.667 & c & 26.333 & $\mathrm{~cd}$ & 224.133 & d \\
\hline & 6919 & 420.333 & fg & 155 & $\mathrm{bc}$ & 140.333 & de & 5.667 & $\mathrm{~cd}$ & 16 & $\mathrm{~d}$ & 147.467 & $\mathrm{e}$ \\
\hline & HM4 & 521.667 & e & 185 & $\mathrm{bc}$ & 174 & d & 5.667 & $\mathrm{~cd}$ & 19.333 & $\mathrm{~cd}$ & 181.133 & de \\
\hline & L901-902 & 644 & $\mathrm{~d}$ & 224 & $\mathrm{bc}$ & 214.333 & $\mathrm{c}$ & 6.667 & $\mathrm{~cd}$ & 24.333 & $\mathrm{~cd}$ & 222.667 & d \\
\hline & QM465 & 611.667 & $\mathrm{~d}$ & 203 & $\mathrm{bc}$ & 204 & $\mathrm{~cd}$ & 6.333 & $\mathrm{~cd}$ & 20.333 & $\mathrm{~cd}$ & 209.067 & $\mathrm{~d}$ \\
\hline & LSD $5 \%$ & & & & & & & & & & & & \\
\hline \multirow[t]{24}{*}{ Resistant } & ZM3 & 92.667 & c & 131 & $a b$ & 30.667 & $\mathrm{~b}$ & 5.667 & $\mathrm{a}$ & 17.333 & $\mathrm{a}$ & 55.467 & $\mathrm{~b}$ \\
\hline & ZLZ & 61.667 & de & 33.667 & $\mathrm{~cd}$ & 20.333 & $\mathrm{bc}$ & 3.667 & $\mathrm{bc}$ & 10.667 & $\mathrm{bc}$ & 26 & de \\
\hline & 13p023 & 35.333 & ef & 47.667 & c & 11.667 & $\mathrm{c}$ & 2.333 & $\mathrm{c}$ & 7 & $\mathrm{bc}$ & 20.8 & ef \\
\hline & HM11046 & 26.333 & fg & 78.667 & $\mathrm{bc}$ & 8.667 & $\mathrm{c}$ & 0.3 & d & 1 & $\mathrm{~d}$ & 22.993 & de \\
\hline & L1779 & 154.333 & $\mathrm{a}$ & 141 & $\mathrm{a}$ & 51.333 & $\mathrm{a}$ & 2 & $\mathrm{~cd}$ & 14.333 & $a b$ & 72.6 & $\mathrm{a}$ \\
\hline & YJ2 & 34.667 & ef & 3 & d & 11.667 & $\mathrm{c}$ & 1.333 & $\mathrm{~cd}$ & 3.333 & $\mathrm{~cd}$ & 10.8 & $\mathrm{f}$ \\
\hline & SM8 & 31.333 & $\mathrm{f}$ & 25.333 & $\mathrm{~cd}$ & 10.333 & $\mathrm{c}$ & 1 & $\mathrm{~cd}$ & 2.667 & $\mathrm{~cd}$ & 14.133 & $\mathrm{f}$ \\
\hline & DZMSR1 & 62.333 & de & 18 & $\mathrm{~cd}$ & 19.333 & $\mathrm{bc}$ & 1.667 & $\mathrm{~cd}$ & 5.333 & $\mathrm{~cd}$ & 21.333 & ef \\
\hline & Z161 & 47.667 & $\mathrm{e}$ & 25.333 & $\mathrm{~cd}$ & 18.667 & $\mathrm{bc}$ & 2 & $\mathrm{~cd}$ & 6 & $\mathrm{~cd}$ & 19.933 & ef \\
\hline & JM20 & 37.667 & ef & 62.667 & $\mathrm{bc}$ & 12.667 & $\mathrm{c}$ & 1.667 & $\mathrm{~cd}$ & 5 & $\mathrm{~cd}$ & 23.934 & de \\
\hline & RO & 7.667 & $\mathrm{~g}$ & 36 & $\mathrm{~cd}$ & 2.667 & $\mathrm{c}$ & 0 & d & 0.333 & $\mathrm{~d}$ & 9.333 & $\mathrm{f}$ \\
\hline & LJM5 & 21.667 & $\mathrm{fg}$ & 12 & $\mathrm{~cd}$ & 7 & $\mathrm{c}$ & 0.667 & d & 2.333 & $\mathrm{~cd}$ & 8.733 & $\mathrm{f}$ \\
\hline & GL1 & 35.333 & ef & 93.333 & $\mathrm{~b}$ & 10.333 & $\mathrm{c}$ & 4.333 & $a b$ & 11.667 & $\mathrm{~b}$ & 31 & $\mathrm{~d}$ \\
\hline & ZYZ4 & 24.667 & $\mathrm{fg}$ & 35 & $\mathrm{~cd}$ & 8.333 & $\mathrm{c}$ & 0 & d & 0 & $\mathrm{~d}$ & 13.6 & $\mathrm{f}$ \\
\hline & L96-103 & 46.333 & ef & 66.667 & $\mathrm{bc}$ & 15.667 & $\mathrm{bc}$ & 3 & $\mathrm{bc}$ & 8.333 & $\mathrm{bc}$ & 28 & de \\
\hline & Z1-59 & 86.667 & $\mathrm{c}$ & 15.667 & $\mathrm{~cd}$ & 29.667 & $\mathrm{~b}$ & 4 & $\mathrm{~b}$ & 11.333 & $\mathrm{bc}$ & 29.467 & de \\
\hline & 13Р022 & 33.333 & ef & 17.667 & $\mathrm{~cd}$ & 12.667 & $\mathrm{c}$ & 2.333 & $\mathrm{c}$ & 6.333 & $\mathrm{c}$ & 14.467 & $\mathrm{f}$ \\
\hline & LM1 & 66.333 & $\mathrm{~d}$ & 97.333 & $\mathrm{~b}$ & 22.333 & $\mathrm{bc}$ & 2.667 & $\mathrm{bc}$ & 9.667 & $\mathrm{bc}$ & 39.667 & $\mathrm{c}$ \\
\hline & $37-30$ & 116.333 & $\mathrm{~b}$ & 42.667 & $\mathrm{c}$ & 37.667 & $\mathrm{a}$ & 5.667 & a & 17.333 & $\mathrm{a}$ & 43.933 & $\mathrm{c}$ \\
\hline & $38-36$ & 15 & $\mathrm{~g}$ & 20.667 & $\mathrm{~cd}$ & 5.667 & $\mathrm{c}$ & 0.667 & d & 2 & $\mathrm{~cd}$ & 8.8 & $\mathrm{f}$ \\
\hline & $39-38$ & 56.333 & de & 25.333 & $\mathrm{~cd}$ & 19 & $\mathrm{bc}$ & 3.333 & $\mathrm{bc}$ & 10.333 & $\mathrm{bc}$ & 22.866 & $\mathrm{e}$ \\
\hline & PZYH & 59.667 & de & 30.667 & $\mathrm{~cd}$ & 19.667 & $\mathrm{bc}$ & 4 & $\mathrm{~b}$ & 12.333 & $a b$ & 25.267 & de \\
\hline & ACS50/2 & 51.667 & de & 118 & $a b$ & 13 & $\mathrm{c}$ & 1.889 & $\mathrm{~cd}$ & 7.667 & $\mathrm{bc}$ & 38.445 & $\mathrm{~cd}$ \\
\hline & LSD $5 \%$ & & & & & & & & & & & & \\
\hline
\end{tabular}


(a)

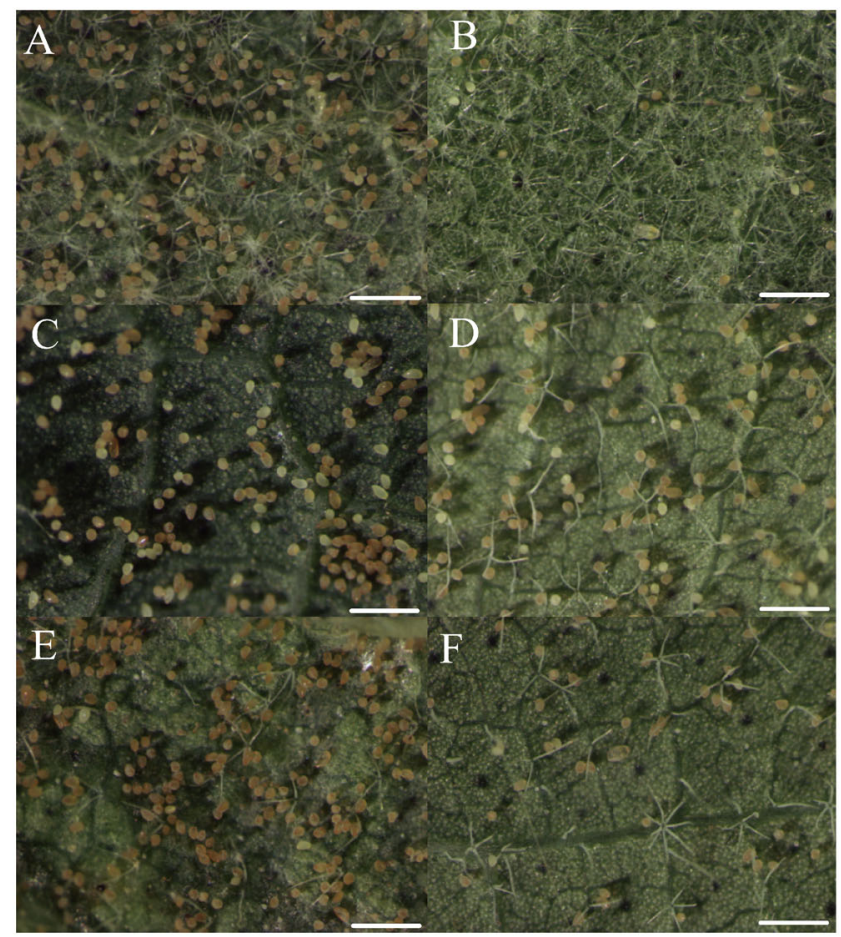

(b)

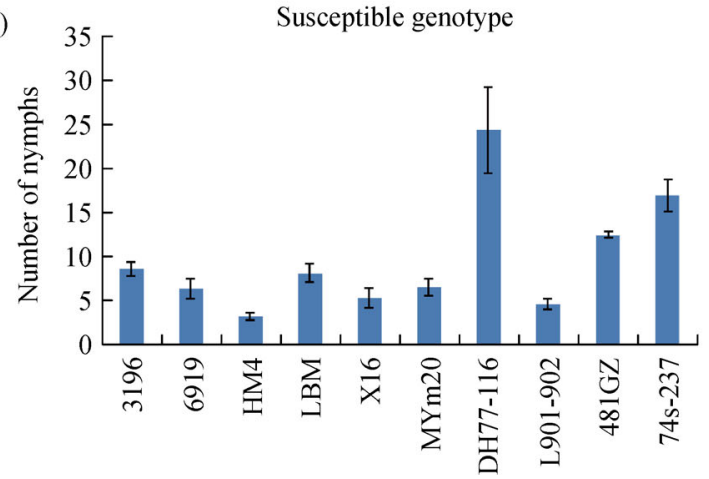

(c)

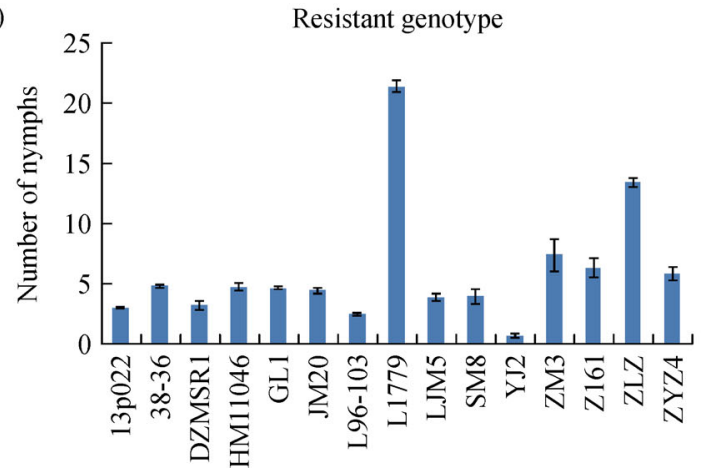

Fig. 4 Nymph densities on the leaves of 25 genotypes. (a) Nymphs on each leaf were counted using a Leica stereo microscope, samples were photographed from three positions to form a triangle. Vernier calipers were used to measure area of the leaves in the photographs with nymphs. Bars $=400 \mu \mathrm{m}$ in A-F; (b, c) Mean number of whitefly eggs and nymphs per $\mathrm{cm}^{2}$ on susceptible genotypes (10 genotypes)

(b) and resistant (15 genotypes) (c) on the fifth leaf from the terminal in greenhouse Exps. 2-3. Back transformed means are plotted.

In the greenhouse experiments, differences in hair length on the underside of leaves were observed among different genotypes and experiments (Table 4). The resistant genotypes, HM11046, ZLZ, 38-36 and DZMSR1, had significantly longer leaf hairs than the other $G$. hirsutum and $G$. arboreum genotypes in these experiments. The results for Exps. 2-3 were mostly similar. Moreover, the same pattern was found among susceptible genotypes, especially, DH77-116 and 74s-237 that had longer leaf hairs than other genotypes.

3.6 Gossypol concentration and number of glands in cotton leaves

The concentration of gossypol, calculated using a standard curve that had a strong linear relationship $(y=0.0136 x+$ $\left.0.072, R^{2}=0.999\right)$, ranged from 2.8 to $14.0 \mu \mathrm{g} \cdot \mathrm{g}^{-1}$ (Fig. 5a). Gossypol concentration was approximately two times higher in the resistant genotypes than the susceptible ones in Exps. 2-3 (Table S2, Fig. 5b and 5c).

The mean number of glands on the underside of leaves in the resistant genotypes was about 81.2 per $\mathrm{cm}^{2}$, which was significantly higher (about 1.7 times more) than susceptible genotypes $\left(49.1\right.$ per $\mathrm{cm}^{2}$ ) (Table 5). In addition, genotypes with fewer glands, e.g., X16 and MYm20, were susceptible genotypes, whereas those with more glands, e.g., 13p022 and Z161, were resistant genotypes.

The glands are important for the storage of gossypol. The analysis also showed that gossypol concentration had a strong positive relationship with glands density (Fig. S3).

\subsection{The relationship between leaf shape and whitefly} resistance

It was also found that $G$. barbadense genotypes, with larger leaves, had higher numbers of adult whiteflies than G. hirsutum genotypes, with normal leaf size. Genotypes with okra-shaped leaves had lower adult whitefly populations and nymph density (Tables 1-3). These relationships were observed in both greenhouse and field experiments.

\subsection{Correlation and weight analysis of whitefly resistance in different cotton genotypes}

The glabrous genotypes, without the effects of leaf hair length and density, were selected to study the correlation between gossypol concentration and glands density on whitefly resistance. The gossypol concentration and glands 
Table 3 Mean leaf hair density of susceptible and resistant genotypes in the greenhouse Exps. 2-3

\begin{tabular}{|c|c|c|c|c|c|c|c|}
\hline \multirow{3}{*}{$\begin{array}{l}\text { Phenotype } \\
\text { Susceptible }\end{array}$} & \multirow{3}{*}{$\begin{array}{c}\text { Genotype } \\
3196\end{array}$} & \multicolumn{6}{|c|}{ Leaf hairs per $\mathrm{cm}^{2}$} \\
\hline & & \multicolumn{2}{|c|}{ Exp. 2} & \multicolumn{2}{|c|}{ Exp. 3} & \multicolumn{2}{|c|}{ Mean } \\
\hline & & 322.66 & e & 66.904 & $\mathrm{~d}$ & 194.782 & e \\
\hline & 6919 & 799.022 & de & 207.286 & $\mathrm{~cd}$ & 503.154 & de \\
\hline & HM4 & 0 & & 0 & & 0 & \\
\hline & LBM & 1451.129 & d & 357.899 & $\mathrm{c}$ & 904.514 & $d$ \\
\hline & $\mathrm{X} 16$ & 213.788 & e & 12.437 & d & 113.113 & e \\
\hline & MYm20 & 0 & & 0 & & 0 & \\
\hline & DH77-116 & 4202.675 & $\mathrm{~b}$ & 1088.381 & $\mathrm{~b}$ & 2645.528 & $\mathrm{~b}$ \\
\hline & L901-902 & 0 & & 0 & & 0 & \\
\hline & $481 \mathrm{GZ}$ & 6681.782 & $\mathrm{a}$ & 1595.488 & a & 4138.635 & a \\
\hline & $74 s-237$ & 3211.371 & $\mathrm{c}$ & 854.999 & $\mathrm{~b}$ & 2033.185 & $\mathrm{c}$ \\
\hline & LSD $5 \%$ & & & & & & \\
\hline \multirow[t]{16}{*}{ Resistant } & 13p022 & 0 & & 0 & & 0 & \\
\hline & $38-36$ & 397.428 & ef & 97.199 & $\mathrm{~cd}$ & 247.314 & e \\
\hline & DZMSR1 & 305.419 & $\mathrm{f}$ & 64.654 & $\mathrm{~cd}$ & 185.037 & ef \\
\hline & HM11046 & 529.32 & e & 116.943 & $\mathrm{~cd}$ & 323.131 & de \\
\hline & GL1 & 412.304 & ef & 91.487 & $\mathrm{~cd}$ & 251.895 & e \\
\hline & JM20 & 977.039 & d & 104.227 & $\mathrm{~cd}$ & 540.633 & d \\
\hline & L96-103 & 0 & & 101.587 & $\mathrm{~cd}$ & 50.793 & ef \\
\hline & L1779 & 10000 & $\mathrm{a}$ & 4744.234 & $\mathrm{a}$ & 7372.117 & $\mathrm{a}$ \\
\hline & LJM5 & 0 & & 0 & & 0 & \\
\hline & SM8 & 31.665 & $\mathrm{~g}$ & 8.555 & d & 20.11 & f \\
\hline & YJ2 & 0 & & 0 & & 0 & \\
\hline & ZM3 & 314.944 & $\mathrm{f}$ & 115.256 & $\mathrm{~cd}$ & 215.1 & ef \\
\hline & Z161 & 0 & & 0 & & 0 & \\
\hline & ZLZ & 1485.31 & $\mathrm{c}$ & 471.308 & $\mathrm{c}$ & 978.309 & $\mathrm{c}$ \\
\hline & ZYZ4 & 5018.715 & $\mathrm{~b}$ & 1396.312 & $\mathrm{~b}$ & 3207.514 & $\mathrm{~b}$ \\
\hline & LSD $5 \%$ & & & & & & \\
\hline
\end{tabular}

Note: Back transformed means in each column followed by the same letter are not significantly different using LSD $(P<0.05)$ on ANOVA of square root transformed data.

density were strongly negatively correlated with whitefly population in Exps. 2-3 (Table S3 ; Fig. 6).

Correlations between leaf hair length and density and whitefly nymphs in G. hirsutum was found for genotypes having a low concentration of gossypol (Table S4). Significant positive correlations between leaf hair density and length, and nymph numbers in Exps. 2-3 (Fig. 7) were also found.

Weight analysis was used to determine the proportion of multiple factors contributing to cotton resistance to whitefly. It was found that leaf hair density had a relative importance in resistance of $45.8 \%$ against adult whitefly populations, while glands density, gossypol concentration and leaf hair length had relative importance of $31.3 \%$, $5.6 \%$, and $17.3 \%$, respectively (Fig. 8a). For whitefly eggs and nymphs, leaf hair density had a relative importances of $52.5 \%$, and leaf hair length, gossypol concentration and gland density had relative importances of $35.2 \%, 5.4 \%$, and $6.9 \%$, respectively (Fig. $8 \mathrm{~b}$ ).

\section{Discussion}

There is no doubt that insect resistance is controlled by multiple factors. Induced resistance describes the process by which changes occur in the host plant, in response to 
Table 4 Mean leaf hair length of susceptible and resistant genotypes in greenhouse Exps. 2-3

\begin{tabular}{|c|c|c|c|c|c|c|c|}
\hline \multirow{3}{*}{$\begin{array}{l}\text { Phenotype } \\
\text { Susceptible }\end{array}$} & \multirow{3}{*}{$\begin{array}{r}\text { Genotype } \\
3196\end{array}$} & \multicolumn{6}{|c|}{ Mean leaf hair length/ $\mu \mathrm{m}$} \\
\hline & & \multicolumn{2}{|c|}{ Exp. 2} & \multicolumn{2}{|c|}{ Exp. 3} & \multicolumn{2}{|c|}{ Mean } \\
\hline & & 34.444 & $a b$ & 59.305 & $a b$ & 46.874 & $a b$ \\
\hline & 6919 & 34.154 & $\mathrm{~b}$ & 55.516 & $a b$ & 44.835 & $\mathrm{~b}$ \\
\hline & HM4 & 0 & & 0 & & 0 & \\
\hline & LBM & 34.097 & $\mathrm{~b}$ & 55.332 & $a b$ & 44.715 & $\mathrm{~b}$ \\
\hline & $\mathrm{X} 16$ & 37.954 & $a b$ & 41.882 & $\mathrm{~b}$ & 39.918 & b \\
\hline & MYm20 & 0 & & 0 & & 0 & \\
\hline & DH77-116 & 44.435 & a & 68.372 & $\mathrm{a}$ & 56.403 & $\mathrm{a}$ \\
\hline & L901-902 & 0 & & 0 & & 0 & \\
\hline & $481 \mathrm{GZ}$ & 36.953 & $a b$ & 56.823 & $a b$ & 46.888 & $a b$ \\
\hline & $74 s-237$ & 42.568 & $a b$ & 65.49 & a & 54.029 & $a b$ \\
\hline & LSD $5 \%$ & & & & & & \\
\hline \multirow[t]{16}{*}{ Resistant } & 13p022 & 0 & & 0 & & 0 & \\
\hline & $38-36$ & 39.201 & $a b$ & 55.815 & $a b$ & 47.508 & $\mathrm{a}$ \\
\hline & DZMSR1 & 34.023 & $\mathrm{~b}$ & 60.196 & $a b$ & 47.11 & $\mathrm{a}$ \\
\hline & HM11046 & 0 & & 63.796 & $\mathrm{a}$ & 31.898 & $\mathrm{~b}$ \\
\hline & GL1 & 32.533 & $\mathrm{~b}$ & 54.542 & $a b$ & 43.538 & $a b$ \\
\hline & JM20 & 23.745 & $\mathrm{c}$ & 51.039 & $a b$ & 37.392 & $a b$ \\
\hline & L96-103 & 0 & & 48.715 & $a b$ & 24.357 & $\mathrm{~b}$ \\
\hline & L1779 & 45.555 & $\mathrm{a}$ & 42.95 & $a b$ & 44.253 & $\mathrm{a}$ \\
\hline & LJM5 & 0 & & 0 & & 0 & \\
\hline & SM8 & 36.917 & $\mathrm{~b}$ & 44.177 & $a b$ & 40.547 & $a b$ \\
\hline & YJ2 & 0 & & 0 & & 0 & \\
\hline & ZM3 & 36.979 & $\mathrm{~b}$ & 52.584 & $a b$ & 44.782 & $\mathrm{a}$ \\
\hline & Z161 & 0 & & 0 & & 0 & \\
\hline & ZLZ & 39.11 & $a b$ & 57.174 & $a b$ & 48.142 & $\mathrm{a}$ \\
\hline & ZYZ4 & 21.047 & $\mathrm{c}$ & 41.852 & $\mathrm{~b}$ & 31.45 & $\mathrm{~b}$ \\
\hline & LSD $5 \%$ & & & & & & \\
\hline
\end{tabular}

Note: Back transformed means in each column followed by the same letter are not significantly different using LSD $(P<0.05)$ on ANOVA of square root transformed data.

pest damage, it can increase the resistance of the plant to further herbivore attack $^{[68]}$ and generally involves biochemical components. Gossypol is a kind of sesquiterpene, particularly involved in mediating interactions and protecting plants from herbivores and pathogens ${ }^{[55,56,69]}$. Gossypol concentration and glands density were found to have strong negative correlations with the whitefly population which demonstrated their importance for whitefly resistance.

Leaf hair density has been implicated in resistance to spider mites ${ }^{[70]}$ and genotypes with high hair density or glabrous leaves had fewer mites, whereas those with intermediate densities had more mites ${ }^{[71]}$. Also, the study of population development together with B biotype adult whiteflies and oviposition preference revealed the glabrous leaf traits reduced oviposition preference ${ }^{[42]}$. These experimental results are largely consistent with our results.

In weight analysis of multiple factors contributing to adult whitefly populations, we found that gland density was more important than gossypol concentration. It is also known that gossypol is one of the most abundant types of terpenoids in the glandular trichomes, which are involved in secondary metabolism synthesis, storage and release. This indicates that other metabolites synthesized and stored in the glands might also contribute to the resistance of cotton plants to adult whiteflies. However, for whitefly 
Table 5 Mean number of glands on susceptible and resistant genotypes in greenhouse Exps. 2-3

\begin{tabular}{|c|c|c|c|c|c|c|c|}
\hline \multirow{3}{*}{$\begin{array}{l}\text { Phenotype } \\
\text { Susceptible }\end{array}$} & \multirow{3}{*}{$\begin{array}{r}\text { Genotype } \\
3196\end{array}$} & \multicolumn{6}{|c|}{ Gland density per $\mathrm{cm}^{2}$} \\
\hline & & \multicolumn{2}{|c|}{ Exp. 2} & \multicolumn{2}{|c|}{ Exp. 3} & \multicolumn{2}{|c|}{ Mean } \\
\hline & & 57 & $\mathrm{c}$ & 56 & $\mathrm{c}$ & 56.5 & $\mathrm{c}$ \\
\hline & 6919 & 72.3 & $\mathrm{bc}$ & 84 & $\mathrm{~b}$ & 78.2 & $\mathrm{bc}$ \\
\hline & HM4 & 75.3 & $\mathrm{~b}$ & 84 & $\mathrm{~b}$ & 79.7 & $\mathrm{bc}$ \\
\hline & LBM & 32.3 & $\mathrm{~d}$ & 24 & d & 28.2 & d \\
\hline & $\mathrm{X} 16$ & 0 & & 0 & & 0 & \\
\hline & MYm20 & 0 & & 0 & & 0 & \\
\hline & DH77-116 & 98 & a & 102 & a & 100 & a \\
\hline & L901-902 & 0 & & 0 & & 0 & \\
\hline & $481 \mathrm{GZ}$ & 90 & $a b$ & 79 & $\mathrm{~b}$ & 79.5 & $\mathrm{~b}$ \\
\hline & $74 s-237$ & 66 & $\mathrm{bc}$ & 52 & $\mathrm{c}$ & 59 & $\mathrm{c}$ \\
\hline & LSD $5 \%$ & & & & & & \\
\hline \multirow[t]{16}{*}{ Resistant } & $13 \mathrm{p} 022$ & 139.3 & a & 166 & $\mathrm{a}$ & 152.7 & a \\
\hline & $38-36$ & 52.3 & $\mathrm{~d}$ & 48 & d & 50.2 & $\mathrm{~cd}$ \\
\hline & DZMSR1 & 100.7 & $\mathrm{bc}$ & 104 & $\mathrm{~b}$ & 102.4 & $\mathrm{bc}$ \\
\hline & HM11046 & 77 & $\mathrm{c}$ & 86 & bc & 81.5 & bc \\
\hline & GL1 & 102.7 & $\mathrm{bc}$ & 108 & $\mathrm{~b}$ & 105.4 & b \\
\hline & JM20 & 81 & $\mathrm{c}$ & 87 & $\mathrm{bc}$ & 84 & $\mathrm{bc}$ \\
\hline & L96-103 & 29 & d & 28 & d & 28.5 & d \\
\hline & L1779 & 81.3 & $\mathrm{c}$ & 64 & $\mathrm{~cd}$ & 72.7 & $\mathrm{c}$ \\
\hline & LJM5 & 109 & $\mathrm{~b}$ & 99 & $\mathrm{~b}$ & 104 & b \\
\hline & SM8 & 81 & $\mathrm{c}$ & 99 & $\mathrm{bc}$ & 90 & bc \\
\hline & YJ2 & 32 & d & 70.3 & $\mathrm{c}$ & 51.2 & $\mathrm{~cd}$ \\
\hline & ZM3 & 86 & $\mathrm{bc}$ & 70 & $\mathrm{c}$ & 78 & $\mathrm{c}$ \\
\hline & Z161 & 129.3 & $a b$ & 159 & $\mathrm{a}$ & 144.2 & a \\
\hline & ZLZ & 31 & d & 30 & $\mathrm{~d}$ & 30.5 & d \\
\hline & ZYZ4 & 86.3 & $\mathrm{bc}$ & 90 & $\mathrm{bc}$ & 88.2 & bc \\
\hline & LSD $5 \%$ & & & & & & \\
\hline
\end{tabular}

Note: Back transformed means in each column followed by the same letter are not significantly different using LSD $(P<0.05)$ on ANOVA of square root transformed data.

eggs and nymphs, the weight contribution of metabolites synthesized and stored in the glands was opposite. Some reports have stated that $G$. hirsutum, with a high gossypol concentration, is considered to be resistant to bollworm, Helicoverpa zea, and the tobacco budworm, H. virescens $^{[49]}$. Moreover, high gossypol concentration can significantly reduce the survival and reproduction of Aphis gossyppii and Propylaea japonica by delaying the hatching of pupae, which greatly reduces the number of generations ${ }^{[72]}$. Notably, the leaf hair densities were found to be highly important for adult whitefly populations as well as eggs and nymphs. Moreover, it has been shown that high leaf hair density can provide a favorable surface environment for attachment ${ }^{[73,74]}$.

In this study over three years, we have conducted a detailed investigation and analysis of whitefly infestation throughout cotton growth and development in two field and five greenhouse experiments, using cotton genotypes from different parts of China. It was found that glabrous leaves were important for resistance to adult whiteflies, while low gossypol concentration and glands density contributed to susceptibility. It appears that within a certain range of leaf hair length and density, the larger and longer hairs allow whitefly adults and eggs to attach more easily to the leaf surface, and likewise for larger and smoother leaf types, but not for okra-shaped leaves. 

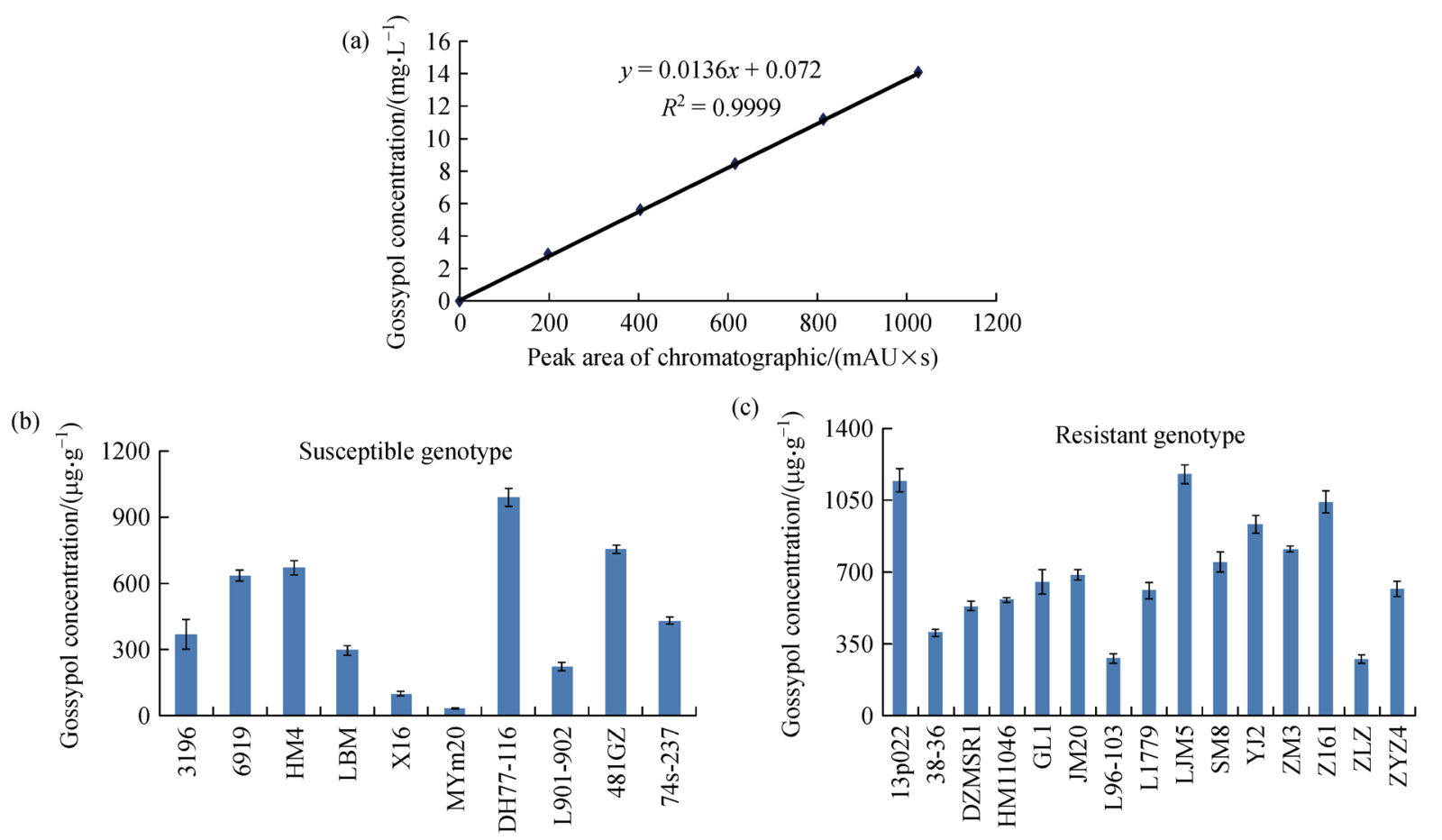

Fig. 5 Gossypol concentrations in the leaves of 25 genotypes quantified HPLC. (a) Six gossypol concentrations from 2.8 to $14.0 \mu \mathrm{g} \cdot \mathrm{g}^{-1}$ were used to establish the standard curve; (b, c) gossypol concentration of 25 genotypes susceptible (b) and resistant genotypes (c) in greenhouse Exps. 2-3.

(a)

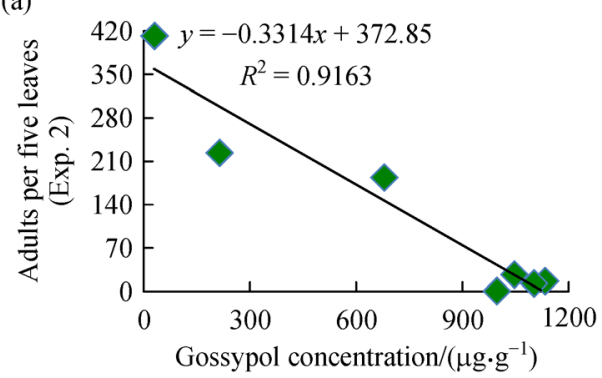

(c)

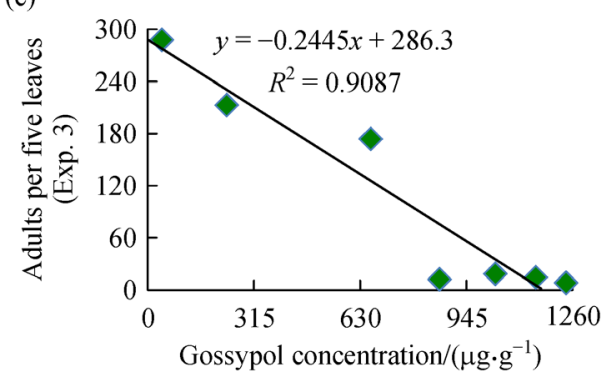

(b)

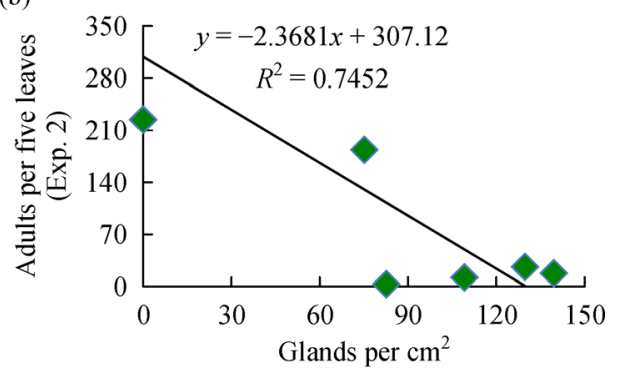

(d)

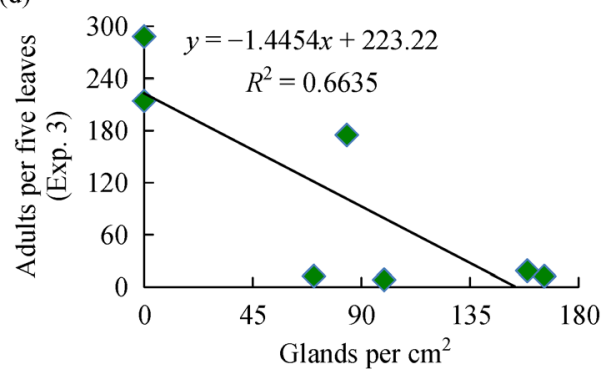

Fig. 6 Gossypol concentration and trichome density were negatively correlated with the population of whitefly per five leaves for glabrous genotypes. (a, b) Gossypol concentration $\left(\mu \mathrm{g} \cdot \mathrm{g}^{-1}\right)$ (a) and glands per $\mathrm{cm}^{2}$ (b) in greenhouse Exp. 2; (c, d) gossypol concentration $\left(\mu \mathrm{g} \cdot \mathrm{g}^{-1}\right)(\mathrm{c})$ and glands per $\mathrm{cm}^{2}(\mathrm{~d})$ in greenhouse Exp. 3 . 
(a)

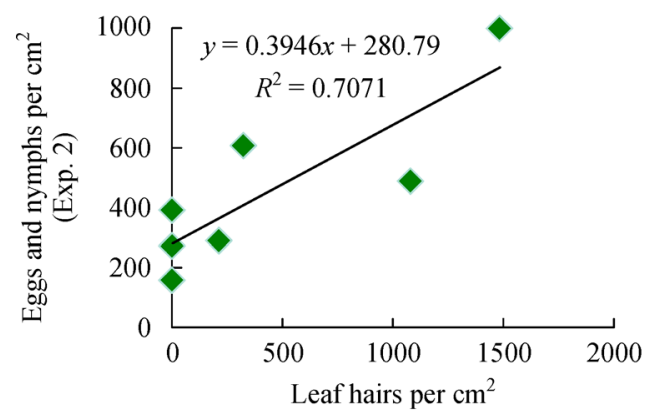

(c)

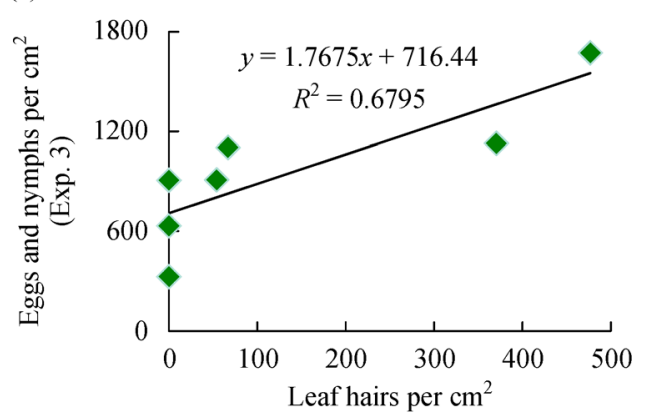

(b)

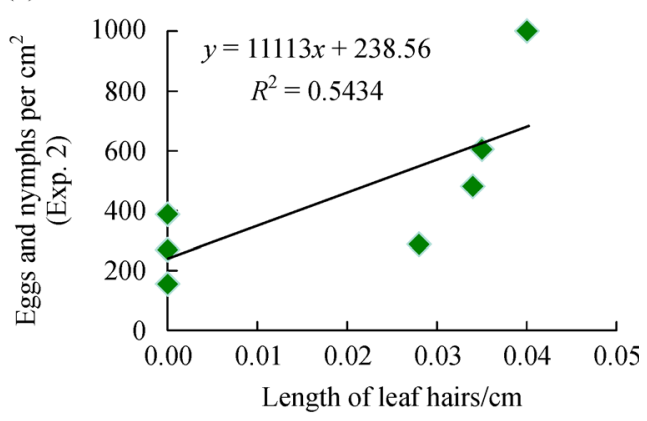

(d)

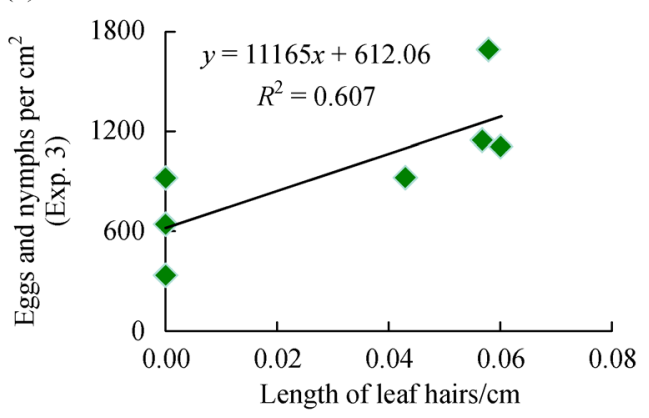

Fig. 7 Leaf hair density and hair length were positively correlated with the density of whitefly nymphs in genotypes with low concentrations of gossypol. (a, b) Leaf hairs per $\mathrm{cm}^{2}$ (a) and leaf hair length (cm) (b) in greenhouse Exp. 2; (c, d) leaf hairs per $\mathrm{cm}^{2}(\mathrm{c})$ and leaf hair length $(\mathrm{cm})(\mathrm{d})$ in greenhouse Exp. 3.
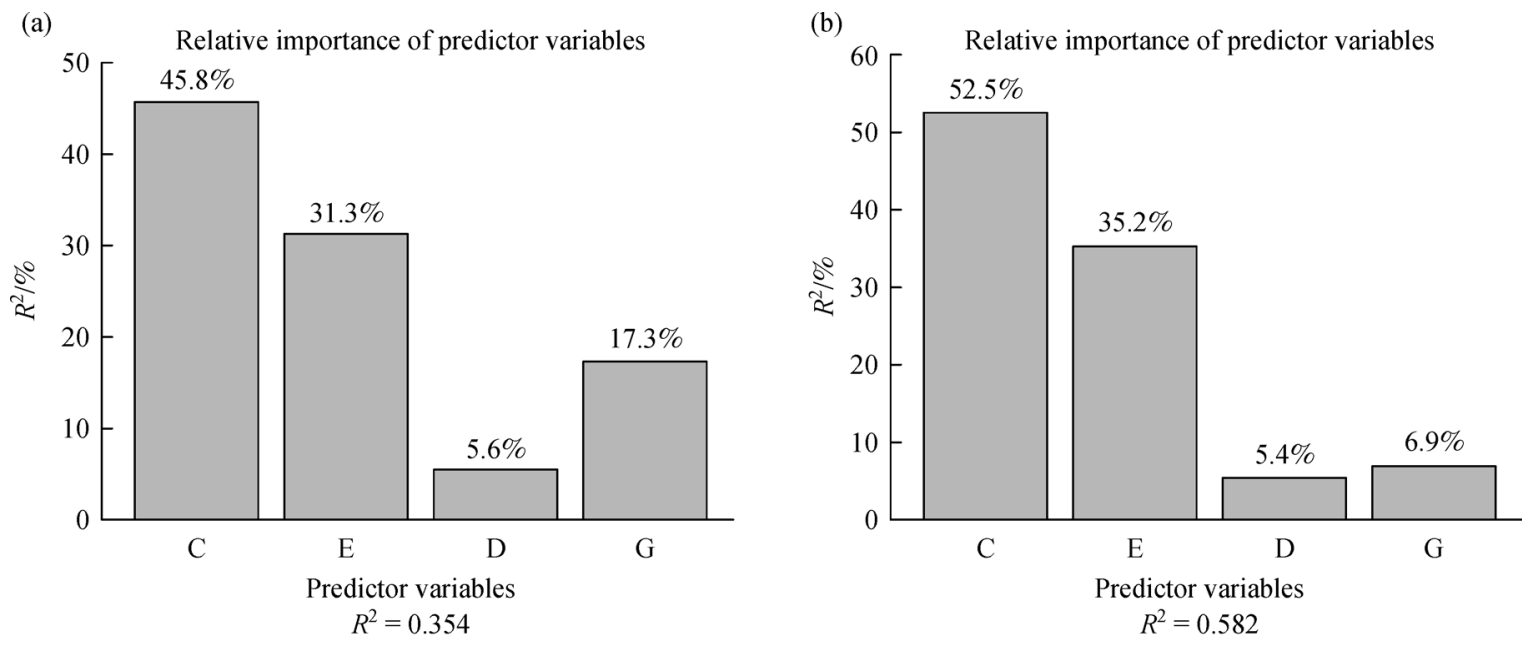

Fig. 8 Relative weight of predictor variables with number of adult whiteflies per five leaves (a) and whitefly nymphs per $\mathrm{cm}^{2}$ (b). C, Leaf hair number per $\mathrm{cm}^{2}$; E, Gland number per $\mathrm{cm}^{2}$; D, Leaf hair length $(\mathrm{cm})$; G, Gossypol concentration $\left(\mu \mathrm{g} \cdot \mathrm{g}{ }^{-1}\right)$. A multiple linear regression model was fitted and the all-subsets regression analysis in R with the regsubsets function from the leaps package ${ }^{[67]}$ was used to choose an optimal combination of the influence factors. Finally, the relative weight of each influence factor was calculated to define their contribution to adult whiteflies per five leaves (a) and whitefly nymphs per $\mathrm{cm}^{2}$ (b).

\section{Conclusions}

This is the first report of a large-scale screening of $B$. tabaci resistance/susceptibility in cotton and the results revealed six different mechanisms of resistance: (1) Okra-shaped leaves reduce adult whitefly oviposition preference;
(2) Greater leaf hair length and densities reduce the density of whitefly eggs and nymphs for genotypes with low concentrations of gossypol through obstructing the feeding process; (3) Glabrous leaves help reduce adult numbers and oviposition preference; (4) Greater gossypol concentration and glands density reduce whitefly numbers on 
glabrous genotypes; (5) Glands on the underside of cotton leaves have an important role in plant-insect interactions; (6) Gossypol in cotton leaves reduces the development and/or survival of whitefly adults. Although yield responses were not determined, these whitefly-resistant genotypes and traits should be considered as candidates for the development of host plant resistant genotypes.

Supplementary materials The online version of this article at https: //doi.org/10.15302/J-FASE-2018223 contains supplementary materials (Figs. S1-S3; Tables S1-S4).

Acknowledgements This work was supported by the National Key Research and Development Plan (2016YFD0100203-9), National Natural Science Foundation of China (31371673), National R\&D Project of Transgenic Crops of Ministry of Science and Technology of China (2016ZX08010001-006) to Professor Shuangxia Jin.

Compliance with ethics guidelines Lizhen Zhu, Jianying Li, Zhongping Xu, Hakim Manghwar, Sijia Liang, Suli Li, Muna Alariqi, Shuangxia Jin, and Xianlong Zhang declare that they have no conflicts of interest or financial conflicts to disclose.

This article does not contain any studies with human or animal subjects performed by any of the authors.

\section{References}

1. Wendel J F,Cronn R C. Polyploidy and the evolutionary history of cotton. Advances In Agronomy, 2003, 78: 139-186

2. James C. Global status of commercialized biotech/GM crops. ISAAA IthacaNova Yorque, 2007

3. Atkinson N J, Urwin P E. The interaction of plant biotic and abiotic stresses: from genes to the field. Journal of Experimental Botany, 2012, 63(10): 3523-3543

4. Razaq M, Aslam M, Shad S A, Naeem M. Evaluation of some new promising cotton strains against bollworm complex. Evaluation, 2004, 15(3): 313-318

5. Dua I, Kumar V, Bhavneet D E A. Genetically modified cotton and its biosafety concerns: a review. Current Concepts in Botany, 2006: 447-459

6. Klümper W, Qaim M. A meta-analysis of the impacts of genetically modified crops. PLoS One, 2014, 9(11): e111629

7. Lu Y, Wu K, Jiang Y, Guo Y, Desneux N. Widespread adoption of Bt cotton and insecticide decrease promotes biocontrol services. Nature, 2012, 487(7407): 362-365

8. Wang Q, Zhu Y, Sun L, Li L, Jin S, Zhang X. Transgenic Bt cotton driven by the green tissue-specific promoter shows strong toxicity to lepidopteran pests and lower $\mathrm{Bt}$ toxin accumulation in seeds. Science China: Life Sciences, 2016, 59(2): 172-182

9. Tian G, Cheng L, Qi X, Ge Z, Niu C, Zhang X, Jin S. Transgenic cotton plants expressing double-stranded RNAs target HMG-CoA reductase (HMGR) gene inhibits the growth, development and survival of cotton bollworms. International Journal of Biological Sciences, 2015, 11(11): 1296-1305

10. Tian J C, Yao J, Long L P, Romeis J, Shelton A M. Bt crops benefit natural enemies to control non-target pests. Scientific Reports, 2015, 5(1): 16636
11. Azimi S, Rahmani S, Tohidfar M, Ashouri A, Bandani A, TalaeiHassanlouei R. Interaction between Bt-transgenic cotton and the whitefly's parasitoid, Encarsia formosa (Hymenoptera: Aphelinidae). Journal of Plant Protection Research, 2014, 54(3): 272-278

12. Naranjo S E, Ruberson J R, Sharma H C, Wilson L, Wu K. The present and future role of insect-resistant genetically modified cotton in IPM, in integration of insect-resistant genetically modified crops within IPM programs. Springer, 2008, 159-194

13. Lu Y, Wu K, Jiang Y, Xia B, Li P, Feng H, Wyckhuys K A G, Guo $\mathrm{Y}$. Mirid bug outbreaks in multiple crops correlated with wide-scale adoption of Bt cotton in China. Science, 2010, 328(5982): 11511154

14. Lu Y H, Qiu F, Feng H Q, Li H B, Yang Z C, Wyckhuys K A G, Wu K M. Species composition and seasonal abundance of pestiferous plant bugs (Hemiptera: Miridae) on Bt cotton in China. Crop Protection, 2008, 27(3-5): 465-472

15. $\mathrm{Lu} \mathrm{Y,} \mathrm{Wu} \mathrm{K}$. Mirid bugs in China: pest status and management strategies. Outlooks on Pest Management, 2011, 22(6): 84-88

16. Boykin L M, Shatters R G Jr, Rosell R C, McKenzie C L, Bagnall R A, De Barro P, Frohlich D R. Global relationships of Bemisia tabaci (Hemiptera: Aleyrodidae) revealed using Bayesian analysis of mitochondrial COI DNA sequences. Molecular Phylogenetics and Evolution, 2007, 44(3): 1306-1319

17. Jin S, Kanagaraj A, Verma D, Lange T, Daniell H. Release of hormones from conjugates: chloroplast expression of $\beta$-glucosidase results in elevated phytohormone levels associated with significant increase in biomass and protection from aphids or whiteflies conferred by sucrose esters. Plant Physiology, 2011, 155(1): 222235

18. Jin S, Zhang X, Daniell H. Pinellia ternata agglutinin expression in chloroplasts confers broad spectrum resistance against aphid, whitefly, Lepidopteran insects, bacterial and viral pathogens. Plant Biotechnology Journal, 2012, 10(3): 313-327

19. Li J, Zhu L, Hull J J, Liang S, Daniell H, Jin S, Zhang X. Transcriptome analysis reveals a comprehensive insect resistance response mechanism in cotton to infestation by the phloem feeding insect Bemisia tabaci (whitefly). Plant Biotechnology Journal, 2016, 14(10): 1956-1975

20. Moran P J, Thompson G A. Molecular responses to aphid feeding in Arabidopsis in relation to plant defense pathways. Plant Physiology, 2001, 125(2): 1074-1085

21. Jones D R. Plant viruses transmitted by whiteflies. European Journal of Plant Pathology, 2003, 109(3): 195-219

22. Mugiira R, Liu S S, Zhou X. Tomato yellow leaf curl virus and tomato leaf curl Taiwan virus invade South-east Coast of China. Journal of Phytopathology, 2008, 156(4): 217-221

23. Mithöfer A, Boland W. Recognition of herbivory-associated molecular patterns. Plant Physiology, 2008, 146(3): 825-831

24. Gatehouse J A. Plant resistance towards insect herbivores: a dynamic interaction. New Phytologist, 2002, 156(2): 145-169

25. Tollrian R, Harvell C D. The ecology and evolution of inducible defenses. New Jersey, USA: Princeton University Press, 1999

26. Wei J, Wang L, Zhu J, Zhang S, Nandi O I, Kang L. Plants attract parasitic wasps to defend themselves against insect pests by releasing hexenol. PLoS One, 2007, 2(9): e852

27. Kempema L A, Cui X, Holzer F M, Walling L L. Arabidopsis 
transcriptome changes in response to phloem-feeding silverleaf whitefly nymphs. Similarities and distinctions in responses to aphids. Plant Physiology, 2007, 143(2): 849-865

28. Santamaria M E, Martínez M, Cambra I, Grbic V, Diaz I. Understanding plant defence responses against herbivore attacks: an essential first step towards the development of sustainable resistance against pests. Transgenic Research, 2013, 22(4): 697-708

29. Carmona D, Fornoni J. Herbivores can select for mixed defensive strategies in plants. New Phytologist, 2013, 197(2): 576-585

30. Hanover J W. Physiology of tree resistance to insects. Annual Review of Entomology, 1975, 20(1): 75-95

31. Poelman E H, Dam N M, Loon J J A, Vet L E M, Dicke M. Chemical diversity in Brassica oleracea affects biodiversity of insect herbivores. Ecology, 2009, 90(7): 1863-1877

32. Bennett R N, Wallsgrove R M. Secondary metabolites in plant defence mechanisms. New Phytologist, 1994, 127(4): 617-633

33. Chiozza M V, O’Neal M E, MacIntosh G C. Constitutive and induced differential accumulation of amino acid in leaves of susceptible and resistant soybean plants in response to the soybean aphid (Hemiptera: Aphididae). Environmental Entomology, 2010, 39(3): 856-864

34. Hanley M E, Lamont B B, Fairbanks M M, Rafferty C M. Plant structural traits and their role in anti-herbivore defence. Perspectives in Plant Ecology, Evolution and Systematics, 2007, 8(4): 157-178

35. Scriber J, Slansky F Jr. The nutritional ecology of immature insects. Annual Review of Entomology, 1981, 26(1): 183-211

36. Awmack C S, Leather S R. Host plant quality and fecundity in herbivorous insects. Annual Review of Entomology, 2002, 47(1): 817-844

37. Glas J J, Schimmel B C J, Alba J M, Escobar-Bravo R, Schuurink R C, Kant M R. Plant glandular trichomes as targets for breeding or engineering of resistance to herbivores. International Journal of Molecular Sciences, 2012, 13(12): 17077-17103

38. Maffei M E. Sites of synthesis, biochemistry and functional role of plant volatiles. South African Journal of Botany, 2010, 76(4): 612631

39. Tissier A. Glandular trichomes: what comes after expressed sequence tags? Plant Journal, 2012, 70(1): 51-68

40. Tian D, Tooker J, Peiffer M, Chung S H, Felton G W. Role of trichomes in defense against herbivores: comparison of herbivore response to woolly and hairless trichome mutants in tomato (Solanum lycopersicum). Planta, 2012, 236(4): 1053-1066

41. Butter N, Vir B. Morphological basis of resistance in cotton to the whitefly Bemisia tabaci. Phytoparasitica, 1989, 17(4): 251-261

42. Miyazaki J, Stiller W N, Wilson L J. Identification of host plant resistance to silverleaf whitefly in cotton: implications for breeding. Field Crops Research, 2013, 154: 145-152

43. Walker G, Natwick E. Resistance to silverleaf whitefly, Bemisia argentifolii (Hem., Aleyrodidae), in Gossypium thurberi, a wild cotton species. Journal of Applied Entomology, 2006, 130(8): 429436

44. Butler G Jr, Henneberry T, Wilson F. Bemisia tabaci (Homoptera: Aleyrodidae) on cotton: adult activity and cultivar oviposition preference. Journal of Economic Entomology, 1986, 79(2): 350-354

45. Sikka S, Sahni V, Butani D K. Studies on jassid resistance in relation to hairiness of cotton leaves. Euphytica, 1966, 15(3): 383-388
46. Butler G Jr, Rimon D, Henneberry T. Bemisia tabaci (Homoptera: Aleyrodidae): populations on different cotton varieties and cotton stickiness in Israel. Crop Protection, 1988, 7(1): 43-47

47. Chu C C, Natwick E T, Henneberry T J. Bemisia tabaci (Homoptera: Aleyrodidae) biotype B colonization on okra- and normal-leaf upland cotton strains and cultivars. Journal of Economic Entomology, 2002, 95(4): 733-738

48. Lukefahr M, Fryxell P A. Content of gossypol in plants belonging to genera related to cotton. Economic Botany, 1967, 21(2): 128-131

49. Lukefahr M, Houghtaling J. Resistance of cotton strains with high gossypol content to Heliothis spp. Journal of Economic Entomology, 1969, 62(3): 588-591

50. Altman D, Stipanovic R, Bell A. Terpenoids in foliar pigment glands of $\mathrm{A}, \mathrm{D}$, and $\mathrm{AD}$ genome cottons: introgression potential for pest resistance. Journal of Heredity, 1990, 81(6): 447-454

51. Hedin P, Parrott W, Jenkins J. Relationships of glands, cotton square terpenoid aldehydes, and other allelochemicals to larval growth of Heliothis virescens (Lepidoptera: Noctuidae). Journal of Economic Entomology, 1992, 85(2): 359-364

52. Correa L, Cividanes F, Gontijo L, Santos-Cividanes T. Effects of cotton cultivars differing in gossypol content on the quality of Aphis gossypii as prey for two species of Coccinellidae. Biocontrol Science and Technology, 2014, 24(12): 1439-1450

53. Greenberg S M, Showler A T, Liu T X. Effects of neem-based insecticides on beet armyworm (Lepidoptera: Noctuidae). Insect Science, 2005, 12(1): 17-23

54. Gershenzon J, Dudareva N. The function of terpene natural products in the natural world. Nature Chemical Biology, 2007, 3(7): 408-414

55. Tholl D. Terpene synthases and the regulation, diversity and biological roles of terpene metabolism. Current Opinion in Plant Biology, 2006, 9(3): 297-304

56. Cheng A X, Lou Y G, Mao Y B, Lu S, Wang L J, Chen X Y. Plant terpenoids: biosynthesis and ecological functions. Journal of Integrative Plant Biology, 2007, 49(2): 179-186

57. Wu G, Guo J Y, Wan F H, Xiao N W. Responses of three successive generations of beet armyworm, Spodoptera exigua, fed exclusively on different levels of gossypol in cotton leaves. Journal of Insect Science, 2010, 10(165): 165

58. Stipanovic R D, López J D Jr, Dowd M K, Puckhaber L S, Duke S E. Effect of racemic, (+)- and (-)-gossypol on survival and development of Heliothis virescens larvae. Environmental Entomology, 2008, 37(5): 1081-1085

59. Kong G C, Daud M K, Zhu S J. Effects of pigment glands and gossypol on growth, development and insecticide-resistance of cotton bollworm (Heliothis armigera (Hubner)). Crop Protection, 2010, 29(8): 813-819

60. Barro P J D, Driver F. Use of RAPD PCR to distinguish the B biotype from other biotypes of Bemisia tabaci (Gennadius) (Hemiptera: Aleyrodidae). Australian Journal of Entomology, 1997, 36(2): 149-152

61. Rao Q, Luo C, Zhang H, Guo X, Devine G J. Distribution and dynamics of Bemisia tabaci invasive biotypes in central China. Bulletin of Entomological Research, 2011, 101(1): 81-88

62. Simon C, Frati F, Beckenbach A, Crespi B, Liu H, Flook P. Evolution, weighting, and phylogenetic utility of mitochondrial gene sequences and a compilation of conserved polymerase chain 
reaction primers. Annals of the Entomological Society of America, 1994, 87(6): 651-701

63. Naranjo S E, Flint H M. Spatial distribution of adult Bemisia tabaci (Homoptera: Aleyrodidae) in cotton and development and validation of fixed-precision sampling plans for estimating population density. Environmental Entomology, 1995, 24(2): 261-270

64. Miyazaki J, Stiller W N, Wilson L J. Identification of host plant resistance to silverleaf whitefly in cotton: implications for breeding. Field Crops Research, 2013, 154(3): 145-152

65. LeBreton J M, Tonidandel S. Multivariate relative importance: extending relative weight analysis to multivariate criterion spaces. Journal of Applied Psychology, 2008, 93(2): 329-345

66. Maechler M, Rousseeuw P, Struyf A, Hubert M, Hornik K, Maechler M, Rousseeuw P, Struyf A, Hubert M, Hornik K. Cluster: cluster analysis basics and extensions. ResearchGate, 2012

67. Lumley T, Miller A. Leaps: regression subset selection. Embo Journal, 2004, 12(12): 4657-4666

68. Karban R, Myers J H. Induced plant responses to herbivory. Annual Review of Ecology and Systematics, 1989, 20(1): 331-348
69. Dudareva N, Pichersky E, Gershenzon J. Biochemistry of plant volatiles. Plant Physiology, 2004, 135(4): 1893-1902

70. Sadras V, Wilson L, Lally D. Water deficit enhanced cotton resistance to spider mite herbivory. Annals of Botany, 1998, 81(2): 273-286

71. Miyazaki J, Stiller W N, Wilson L J. Novel cotton germplasm with host plant resistance to twospotted spider mite. Field Crops Research, 2012, 134: 114-121

72. Gao F, Zhu S R, Sun Y C, Du L, Parajulee M, Kang L, Ge F. Interactive effects of elevated $\mathrm{CO}_{2}$ and cotton cultivar on tri-trophic interaction of Gossypium hirsutum, Aphis gossyppii, and Propylaea japonica. Environmental Entomology, 2008, 37(1): 29-37

73. Björkman C, Ahrné K. Influence of leaf trichome density on the efficiency of two polyphagous insect predators. Entomologia Experimentalis et Applicata, 2005, 115(1): 179-186

74. Naveed M, Anjum Z I, Khan J A, Rafiq M, Hamza A. Cotton genotypes morpho-physical factors affect resistance against Bemisia tabaci in relation to other sucking pests and its associated predators and parasitoids. Pakistan Journal of Zoology, 2011, 43(2): 229-236 